\title{
Wind, String and Other Instruments
}

This chapter will discuss instruments that are played on their own, or in combination with one or two other instruments, mostly for entertainment. In the overview in Section 1.2 it was already mentioned that the Outer Baduy have four types of flutes, all made of bamboo: elét, suling lam(b)us, suling kumbang and tarawélét (also called taléot). They also have four string instruments: the kacapi (pantun) zither, (kacapi) siter flat zither, the two-string bowed lute rendo and the four-string bowed lute viol (violin). After discussing these wind and string instruments, the last section will briefly mention a few other instruments that may also be played on their own: gambang and calung xylophones, and karinding Jew's harps. Of the here mentioned instruments the Inner Baduy are only allowed to play the side-blown flutes suling kumbang and tarawélét, the kacapi pantun zither and the karinding Jew's harp.

Baduy say that the lamus, kumbang and tarawélét flutes are also used for courting purposes. In a way this is not surprising, as in many regions of the world flutes are thought to have magical powers. In the 193os Kruyt reported this for Indonesian flutes, mainly in Kalimantan, Sulawesi and Papua. He described the Indonesian flute as a 'vessel full of life force with which one may create life', and the creative powers of the wind, 'the breath of the universe', are explicitly mentioned. Kruyt's conclusion is that in the past the ritual use of flutes in Indonesia may have been more common than in the 1930s (Kruyt 1938: 249, 268, 269).

Like the Baduy kacapi pantun, the rendo and gongs in the keromong ensemble have no decorations, except for a possible white cross (tumbal) to protect the player and the audience from evil spirits; see also Sections 6.4 and 7.4 above. This chapter will not discuss the magical powers of Baduy flutes and other musical instruments and rather concentrate on the physical aspects and the produced music. The instruments will be briefly described, with special attention to the two side-blown flutes and the music produced on these instruments, because nowadays they are rarely found in the Outer Baduy area. The other instruments are more common, and very similar instruments may also be found outside the Baduy area, although we only have limited information on this.

First the flutes will be discussed and thereafter the string and other instruments. Figure 52 shows eight flutes that I bought, or that were given as a present to me in different years. The flutes are listed with the year in which I obtained this specimen. The tarawélét and suling kumbang obtained in 2014 were 


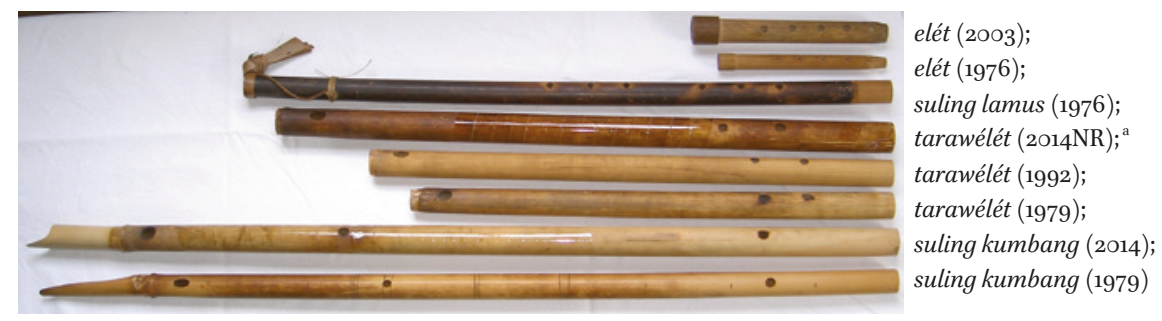

FIGURE 52 The four types of Baduy flutes. From top to bottom: two elét, one suling lamus, three tarawélét and two suling kumbang

a Karamaén from Cibéo made two tarawélét that I bought on 5 June 2014 and I distinguish these flutes by $2014 \mathrm{R}$ and $2014 \mathrm{NR}$. I do not possess tarawélét $2014 \mathrm{R}$ (2014 Recorded), the one on which Karamaén played in my film and audio recordings that day. That tarawélét was given to my assistant Mumu. The Non-Recorded tarawélét that I possess is indicated by $2014 \mathrm{NR}$. It appeared that these two tarawélét (2014R and $2014 \mathrm{NR}$ ) although having similar appearances, produced slightly different notes (see below).

damaged during the journey, as will be explained below, and repaired by the present author with transparent tape.

A photograph showing the elét (1976), suling lamus (1976) and tarawélét (1979) was earlier published in Van Zanten (1989:100), in the same picture with three other Sundanese end-blown bamboo flutes: six-finger hole suling, fourfinger hole suling degung and the four-finger hole suling saléndro. From that picture it becomes clear that the Baduy suling lamus is very similar to the sixfinger hole suling as used in, for instance, Cianjuran music. Whereas the Baduy elét, suling kumbang, and tarawélét are always played on their own, the suling lamus may be played on its own, but also in combination with the kacapi and/ or the rendo. Such trio was already reported by Van Hoëvell $(1845: 428)$ and it is still used, also with a violin and flat kacapi siter, instead of the rendo and kacapi pantun. See Section 7.3 above, in which I described such instrumental group accompanying the female vocalist Raidah. Further, apart from the mentioned flutes, there are other instruments not blown by human beings but by the wind (Aeolian flutes): calintuh pipes, and the kolécér idiophone, a kind of propeller: see Section 1.2 and Figure 9 above.

Below the flutes will first be described and the musical aspects discussed, such as the circular breathing technique used for the two end-blown flutes, suling lamus and elét. This technique is not used in the present-day playing of the $60-62 \mathrm{~cm}$ suling, very similar to the Baduy suling lamus, in the other parts of West Java. As far as I know, in the Sundanese region outside the Baduy area this circular breathing technique for wind instruments is only used for the Sundanese shawm (double reed wind instrument): tarompét. The circular 
breathing technique is common all over the world, though, and has already been applied for many centuries, not only for playing musical instruments, but also for producing crafts by smiths and glass blowers.

The kumbang and tarawélét are not blown with circular breathing, and blown in a more discontinuous way and with short breathing pauses. These flutes produce part of the main notes by using overtones of the lowest notes, as will be explained below.

\subsection{Kumbang Flute}

The suling kumbang is a transverse or side-blown flute with two finger holes. Suling kumbang may mean 'flute of the bumblebee' and the kumbang (or bangbara) bumblebee is a metaphor for someone in love. At the side of the blowing hole is a piece of about $10 \mathrm{~cm}$ of bamboo added to the natural partition (ruas) in the bamboo and in the form of a spearhead; this piece seems to have no musical function. Some people remarked that the flute with a sharpened point could be used to defend the player when attacked by a tiger (A1976: 33-34). Hidding (1932: 79-80) mentions the maung kumbang, a black tiger, and tells us that a man of nobility may turn into a tiger and that therefore people do not talk about a 'tiger' in the forest, but about the 'nobleman (ménak) of the forest'. It may be that the name of the kumbang has been derived from this association. Anyway, the pointed end seems not suitable for defending yourself against a tiger; the large knife (golok) that every Baduy man wears seems far more suitable for this purpose, although probably also not sufficient. Moreover, today tigers are no longer to be found in Kanékés.

Here I will present an anecdote about this flute with a sharp point attached to it. In June 2014 the suling kumbang just bought from Karamaén from Cibéo did not fit my suitcase and I had wrapped it in paper to be carried as cabin luggage on the plane. However the airline personnel in Jakarta Cengkareng Airport did not allow this. Especially when they saw the sharpened point at the end of the flute they said that this would never pass the security check. The sharpened point of the suling kumbang may have been associated with the bambu runcing, the sharpened bamboo spears that were used by Indonesian villagers, in particular during the independence war against the Dutch in 1945-1949. ${ }^{1}$ In this situation the best choice seemed to send the flute with the

1 Geise (1952: 110) mentions the story Budak Buncireung, in which a spear from tamiang bamboo (tamiang pugur) from which the leaves and branches have been removed, should be used to kill the monster Si Iwak Gentur. 
suitcase in the luggage compartment and, in an improvised way, wrapped only in paper with one of my shirts around it. On arrival in Amsterdam the flute had three cracks of about $10-20 \mathrm{~cm}$ near the first finger hole. Unfortunately the tarawélét packed in my suitcase was also damaged at this journey! Fortunately I could repair the damage with transparent tape such that the flutes can be used again.

I have two suling kumbang made in the Inner Baduy area. The first one was presented to me together with a tarawélét by Ukang Sukarna, then the secretary (carik) of Kanékés on 16 July 1979 (A1979: 2). The second kumbang was bought on 5 June 2014 from player Karamaén from Cibéo, who had made this flute himself (A2014-1: 56-59; audio and film recording). The kumbang are said to be made from tamiang bamboo and the lengths are 69.8 and $72.5 \mathrm{~cm}$, as measured on the inside from the partition in the bamboo until the open end, that is, without the sharp point. The 1979 flute seems indeed to be made from tamiang bamboo. However, the 2014 flute is thicker and I am not quite sure that this is tamiang (what Karamaén told me), the kind of bamboo used for most Sundanese flutes.

Karamaén explained that there is a relation between the outer circumference of the flute near the blowing hole and the position of the two finger holes and the blowing hole. The circumference (beulitan; literally: what you wind around something) was measured with a piece of strong grass or something similar. This length was called one rumbak. ${ }^{2}$ The total length of the kumbang from the partition to the open end should be about 9 rumbak. The position of the finger holes is also expressed in rumbak units. The second finger hole, nearest to the open end, is taken about $1 \frac{1}{2}$ rumbak from the end of the flute; the distance between the two finger holes should be about $5^{-} 5^{1 / 2}$ rumbak and the distance between the first finger hole and the partition should be about $2 \frac{1}{2}$ rumbak. The mouth hole is a few centimetres from the partition in the bamboo; Karamaén did not express this last distance in rumbak. For the flute made by Karamaén in 2014, the outer diameter near the mouth hole of the kumbang is $2.6 \mathrm{~cm}$, so for this flute one rumbak is about $2.6 \mathrm{x} \pi=8.2 \mathrm{~cm}$. Similarly, for the 1979 kumbang one rumbak is $2.2 \mathrm{x} \pi=6.9 \mathrm{~cm}$. In Table 17 below I have presented some distances on these flutes in $\mathrm{cm}$ and also in rumbak units. It may be seen that on these two kumbang the actual distances in rumbak do not deviate too much from Karamaén's theoretical model.

2 I did not find rumbak as a measure of unit length in KUBS (1976), Zoetmulder (1982) and Eringa (1984). However, it may be related to what is given by Eringa and $K U B S$ as the Sundanese word tumbak, a measure of length of about 3.77 metre. Eringa gives this as the old Dutch measure of length: a Rijnlandse roede. 
TABLE 17 Measurements of two kumbang flutes in $\mathrm{cm}$

Year in which the suling kumbang $\quad 1979$ (July) 2014 (June)
was obtained

\begin{tabular}{|c|c|c|c|c|c|c|}
\hline & $\mathbf{c m}$ & & rumbak & $\mathbf{c m}$ & & rumbak \\
\hline Total length of flute & 81.7 & & & 83 & & \\
\hline $\begin{array}{l}\text { Length from partition to open end } \\
\text { (inside measurement) }\end{array}$ & & 69.6 & 10.1 & & 72.5 & 8.8 \\
\hline Length of sharpened point & & 11.7 & & & 9.8 & \\
\hline Width of partition & & 0.4 & & & 0.7 & \\
\hline $\begin{array}{l}\text { Outer diameter at about } 5 \mathrm{~cm} \text { from } \\
\text { partition, almost at the position of the } \\
\text { mouth hole }\end{array}$ & 2.2 & & & 2.6 & & \\
\hline 1 Rumbak & $\begin{array}{l}2.2 \times \\
\pi=6.9\end{array}$ & & 1 & $\begin{array}{l}2.6 \mathrm{x} \\
\pi=8.2\end{array}$ & & 1 \\
\hline $\begin{array}{l}\text { Outer diameter at about } 5 \mathrm{~cm} \text { from the } \\
\text { open end of flute }\end{array}$ & 2.3 & & & 2.7 & & \\
\hline $\begin{array}{l}\text { Inner diameter at the open end of the } \\
\text { flute }\end{array}$ & 1.7 & & & 2.1 & & \\
\hline $\begin{array}{l}\text { Second finger hole (farthest from } \\
\text { mouth hole) }\end{array}$ & & & & & & \\
\hline Lower edge, position from open end & 11.5 & & 1.7 & 12.2 & & 1.5 \\
\hline Upper edge, position from open end & 12.2 & & & 13.1 & & \\
\hline Diameter & 0.7 & & & $0.8-0.9$ & & \\
\hline $\begin{array}{l}\text { Distance to first finger hole (lower } \\
\text { edges) }\end{array}$ & 35.1 & & 5.1 & 38.4 & & $4 \cdot 7$ \\
\hline First finger hole (nearest to mouth hole) & & & & & & \\
\hline Lower edge, position from open end & 46.6 & & & 50.6 & & \\
\hline Upper edge, position from open end & $47 \cdot 3$ & & & 51.4 & & \\
\hline Diameter & $0.6-0.7$ & & & $0.8-0.9$ & & \\
\hline Distance to mouth hole (lower edges) & $19 \cdot 4$ & & & 18.9 & & \\
\hline $\begin{array}{l}\text { Distance lower edge to partition } \\
\text { Mouth hole }\end{array}$ & 23.0 & & $3 \cdot 3$ & 21.7 & & 2.6 \\
\hline Lower edge, position from open end & 66.0 & & & $69 \cdot 3$ & & \\
\hline Upper edge, position from open end & $67 \cdot 4$ & & & 70.7 & & \\
\hline Diameter & $0.7-1.4$ & & & $1.1-1.4$ & & \\
\hline Distance to partition (lower edges) & 3.6 & & & 3.2 & & \\
\hline $\begin{array}{l}\text { Ratio length from partition: inner } \\
\text { diameter }\end{array}$ & 41 & & & 35 & & \\
\hline
\end{tabular}


On 20 July 1976 I made audio recordings of three songs played by the Outer Baduy Sarjai from Gajéboh, but I did not get the names of these songs. In 1992, 2003 and 2013 I could not find any Outer Baduy who played suling kumbang. It was only in 2014 that I recorded the suling kumbang again, played by the Inner Baduy Karamaén from Cibéo. I met Karamaén for the first time in 2003 and then he played the kacapi. In 2014 Karamaén explained that the Inner Baduy only play the suling kumbang and the tarawélét in a shed in the fields (saung huma) and not in the hamlets (lembur). On the request of Karamaén the June 2014 recording therefore took place in a shed in the fields near the new hamlet Cicampaka, between the Outer Baduy hamlets Cihulu and Kadujangkung, just after Cicampaka had officially been recognized as a new Baduy hamlet by the leaders in the nukuh lembur ceremony (see Section 6.4).

The musical repertoire of the suling kumbang is limited. In 2014 Karamaén played three songs: Noong Sosog ('To have a look at the ditch [with fish trap]'), Pileuleuyan ('Have a good trip' - when going away to start work in the gardens, according to Karamaén) and Noong Buwu ('To have a look at the fish trap'). ${ }^{3}$ He told that these were the only songs that he knew and that he had learned the songs from his family. He added that in the whole Inner Baduy area on the suling kumbang you would only hear these three songs played and the songs were not played on other instruments. As mentioned already, the suling kumbang players do not use the circular breathing technique that is applied when playing the end-blown flutes: the Outer Baduy elét and suling lamus (lamus/lambus means 'bellows'). When playing Karamaén kept the kumbang and tarawélét flutes pointing to his right side; for both instruments he used his right forefinger for closing the second finger hole, farthest from the mouth hole, and his left forefinger for closing the first finger hole, nearest to the mouth hole.

The production of notes on the kumbang by Karamaén is presented in Table 18. The different notes are produced by opening and closing the two holes and by blowing louder or softer to produce overtones (strengthening certain harmonics). As compared to the length, the inner diameter of the bamboo tube (the bore) of the kumbang is too narrow to produce the fundamentals. Therefore the lowest produced notes on the kumbang are the first overtones: octaves of the corresponding fundamentals. If the player blows harder, the next produced note will be the second overtone of the fundamental and a fifth (about 700 cent) higher than the first overtone. Blowing harder again will produce the

3 I am not sure about the meaning of sosok. Coolsma (1884) gives sosokan = susukan, ditch, small canal. It seems that in this context this ditch is used for placing the fish trap (buwu). 


\begin{tabular}{|c|c|c|c|c|c|}
\hline \multicolumn{3}{|c|}{$\begin{array}{l}\text { Mouth hole and finger } \\
\text { holes (as seen from } \\
\text { player) }\end{array}$} & \multirow{2}{*}{$\begin{array}{l}\text { lowest octave: first } \\
\text { overtone of } \\
\text { fundamental } \\
\mathrm{a}^{1 \#}\end{array}$} & \multirow{2}{*}{$\begin{array}{l}\text { second } \\
\text { overtone of } \\
\text { fundamental }\end{array}$} & \multirow{2}{*}{$\begin{array}{l}\text { third } \\
\text { overtone of } \\
\text { fundamental }\end{array}$} \\
\hline$[\mathrm{M}$ & $\bullet$ & •) & & & \\
\hline$[\mathrm{M}$ & $\bullet$ & ○) & $c^{2}$ & $\mathrm{~g}^{2}$ & \\
\hline$[\mathrm{M}$ & $\circ$ & ०) & $\mathrm{d}^{2} \#$ & & \\
\hline \multicolumn{6}{|c|}{$\begin{array}{l}\text { The } \mathrm{f}^{2} \text { may also be produced by opening the hole closest to the mouth hole } \\
\text { and keeping the other hole closed: }\end{array}$} \\
\hline$[\mathrm{M}$ & 0 & •) & & & \\
\hline
\end{tabular}

third overtone that is a fourth (about 5oo cent) higher than the second overtone (see also Marcuse 1975: 554).

In Table 17 the ratio of this length of the flute (from the partition) to the inner diameter is given as $41(=69.6: 1.7)$ for kumbang 1979 and $35(=72.5: 2.1)$ for kumbang 2014. On the other side-blown flutes of the Baduy, the tarawélét to be discussed in the next section, overtones are also used as a major addition to the tone material. However, on the tarawélét the fundamentals can be produced because the bore (inner diameter) is relatively wider than on the kumbang. The ratios length of flute: inner diameter are given in Table 18 below: 22 (= 43.8: 2.0) for tarawélét 1979, 21-25 (= 48.0: 2.3-1.9) for tarawélét 1992 and 15 (= 57.3: 2.8) for tarawélét 2014NR. These tarawélét values are lower than for the kumbang that cannot produce the fundamentals.

It should be understood that the produced notes are represented by approximations of Western tones (equal-tempered model with $\mathrm{a}^{1}=440 \mathrm{OHertz}$ ). It is easy to blow a little harder or softer on the flutes (all kinds: kumbang, tarawélét, lamus and elét) and produce a slightly higher or lower tone. In the used outline of the kumbang in Table 18, $\mathrm{M}$ indicates the mouth hole, $\mathrm{O}$ is an open finger hole and $\bullet$ a closed finger hole; further square bracket '[' indicates the closed end near the mouth hole and the round bracket ')' the open end of the flute.

By strengthening the higher harmonics the player can cover a whole octave with five notes. Karamaén used glissando from one note to another and occasionally did not open a hole entirely, so that a kind of 'in-between' note was produced. This happened several times when he played the grace note higher than $\mathrm{f}^{2}$ (both finger holes closed); in this fast movement the finger on the last 
finger hole was opened only partially and this produced $\mathrm{f}^{2} \#$ rather than $\mathrm{g}^{2}$. In the Music Transcriptions $\operatorname{Tr} 8$ and $\operatorname{Tr} 9$ I have always notated this as $\mathrm{g}^{2}$.

Ordering the notes from low to high frequency (from 'large'/gedé, to 'small'/ leutik), we may present the notes produced by the suling kumbang as played by Karamaén on 5 June 2014 in approximate Western staff notation (with $\mathrm{a}^{1} \equiv 440$ Hertz) as $\mathrm{a}^{1} \#$ (or b $\mathrm{b}^{1}$-flat), $\mathrm{c}^{2}, \mathrm{~d}^{2} \#$ (or $\mathrm{e}^{2}$-flat), $\mathrm{f}^{2}, \mathrm{~g}^{2}, \mathrm{a}^{2} \#$ (or $\mathrm{b}^{2}$-flat). These five notes may be considered to form an equidistant pentatonic tone system: saléndro.

As said, Karamaén produced the note $\mathrm{f}^{2}$ by overblowing the lowest note, but this note could also be produced by opening only the finger hole closest to the mouth hole. This seems the better way for producing this fourth note. According to my field notes this was also done on the kumbang that I tried in Kanékés in 2003 and for the flute obtained in 1979. In April 2003 I measured the notes of a suling kumbang that belonged to Arwan from Kaduketug 1 (neighbour to village head Daénah) by ear. Arwan had obtained the flute from his father and it had been made in the Inner Baduy area, he said (A2003-2: 13). The flute was about $64 \mathrm{~cm}$ long. The relative notes, measured by ear and with reference to a tuning fork with $\mathrm{a}^{1} \equiv 44 \mathrm{OHz}$, were more or less consistent with the more precise measured notes of the kumbang in 2014 and 1979. The notes and their production are listed in Table 19, with the exception of the 1976 kumbang for which I do not have this information.

From Table 19 it follows that the four suling kumbang each produce notes, likely to be taken from some system that is almost equidistant pentatonic. That is, the octave is divided in five almost equal tone intervals of 240 cent. Outside the Baduy area such division is called the saléndro tone system, and currently Baduy also use this term (see Section 5.1).

$\operatorname{Tr} 8$ and Tr 9 present the Music Transcriptions in Western staff notation of the kumbang pieces Noong Sosog and Pileuleuyan as played by Karamaén on 5 June 2014. Again, the two flat signs at the beginning of the staff line have nothing to do with the Western concept of 'key', but are just meant to avoid writing flat-signs for each individual note e and $b$. As said, especially the fast grace note written as $\mathrm{g}^{2}$ often sounds more like $\mathrm{g}^{2}$-flat $/ \mathrm{f}^{2} \#$, because in the production the right finger hole is only partially opened.

Music Transcription Tr 11 presents the transcription of the kumbang piece 1 as played by Sarjai from Gajéboh on 20 July 1976. I do not have this kumbang and also no film or still images that would give information on the production of the notes that were played at that time. Therefore I first presented a PRAAT picture with the played frequency during the 45 seconds of the song in Music Transcription Tr 10. It becomes clear that on Sarjai's kumbang the lowest notes $\mathrm{c}^{2}, \mathrm{~d}^{2}$ and $\mathrm{e}^{2}$ are being played, and also notes $\mathrm{g}^{2}$, and $\mathrm{c}^{3}$ that are probably overblown notes. The notes $\mathrm{a}^{2}$-flat+ and $\mathrm{b}^{2}$-flat- are more problematic. I assume 
Flutes obtained in 1979 (tube length without sharpened end: $69.6 \mathrm{~cm}$ ), the one measured in the field $2003(64 \mathrm{~cm})$, and the one played by Karamaén in $2014(72.5 \mathrm{~cm})$. I have no pictures of the kumbang played by Sarjai in 1976 (first row), and therefore no information how the notes were actually produced on his flute. I guess it is similar to what was obtained for the other three flutes; I put the two notes $\mathrm{a}^{2}$-flat $/ \mathrm{a}^{2}$ on this flute in the same column.

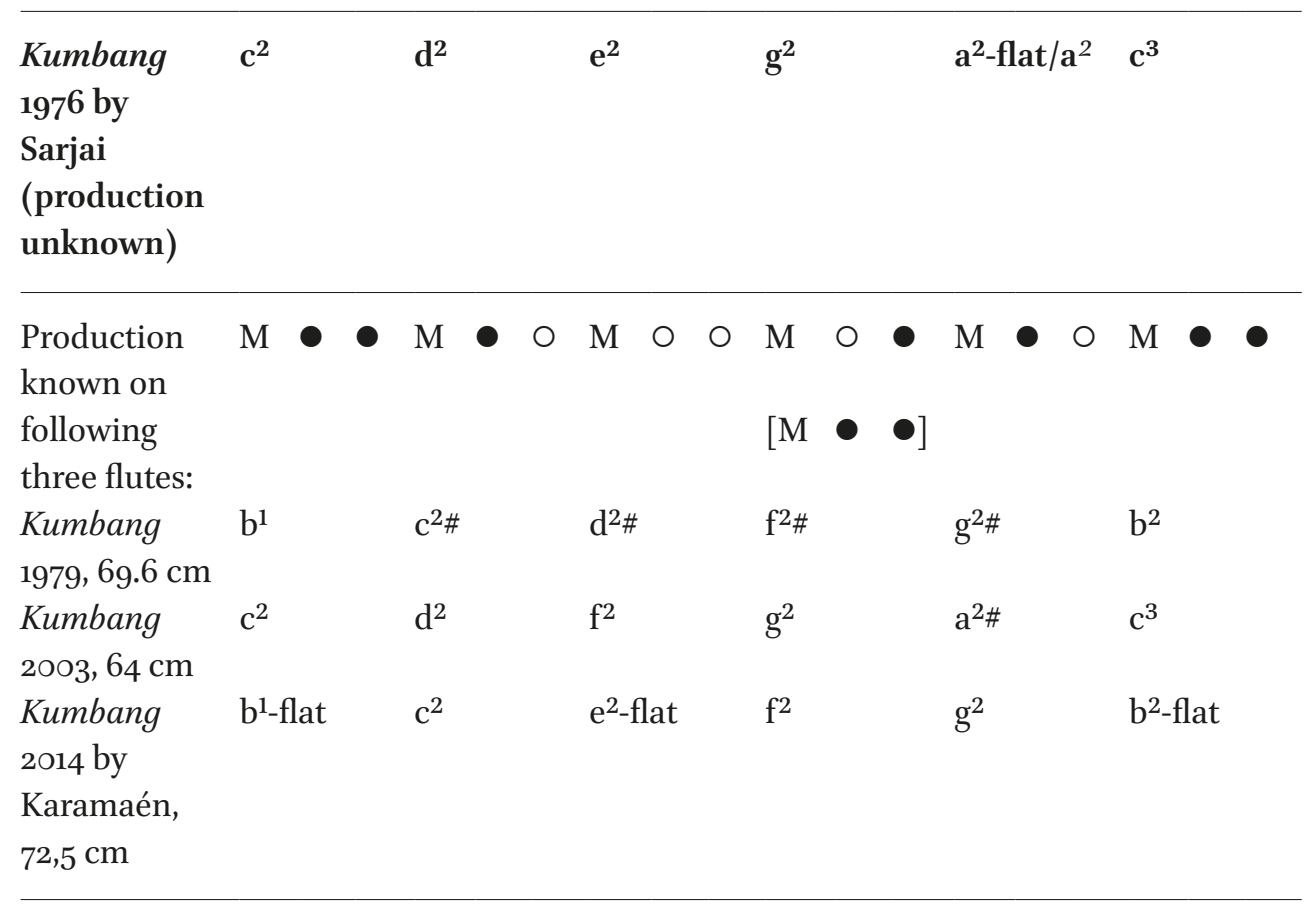

that the long notes $\mathrm{a}^{2}$-flat+ are produced by overblowing the $\mathrm{d}^{2}$. The 'extra' note in between the 'saléndro' notes, slightly lower than $\mathrm{b}^{2}$-flat is always very short (written as grace note) and might be produced by opening and closing a hole for a very short time. This would need further investigation. Sarjai's first piece, represented in the PRAAT picture of Music Transcription $\operatorname{Tr} 10$, has been transcribed in staff notation in Music Transcription Tr 11 and may be heard in $<\mathrm{AV}_{22}>$.

From these transcriptions it becomes clear that both kumbang players use many notes that I have notated as grace notes, smaller in size than the 'notes of the melody'. As already remarked in Section 5.1 (transcription of music for 


\section{Noong Sosog}

Suling kumbang played by Karamaén from Cibéo, 2014

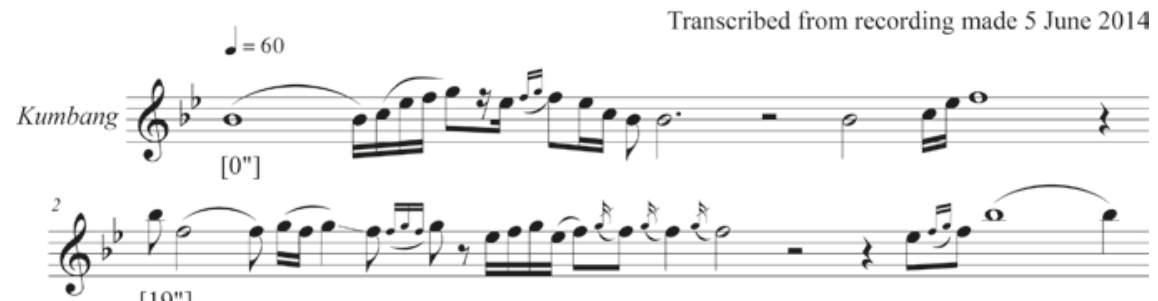

[19"]
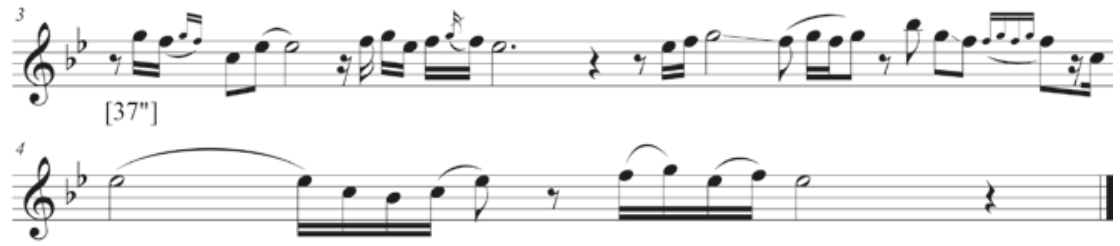

[52"]

[end: 58 "]

MUSIC TRANSCRIPTION TR 8 Noong Sosog played on kumbang flute by Karamaén, 5 June 2014. $<\mathrm{AV} 2 \mathrm{O}>$

\section{Pileuleuyan}

Suling kumbang played by Karamaén from Cibéo, 2014

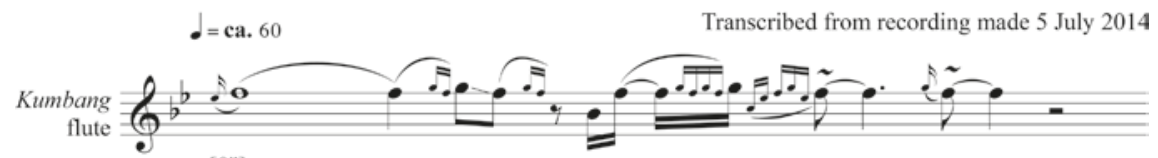

$\left[0^{\prime \prime}\right]$

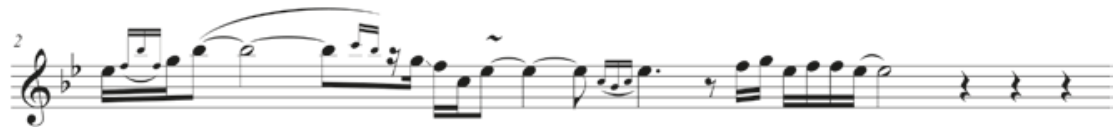

[19"]

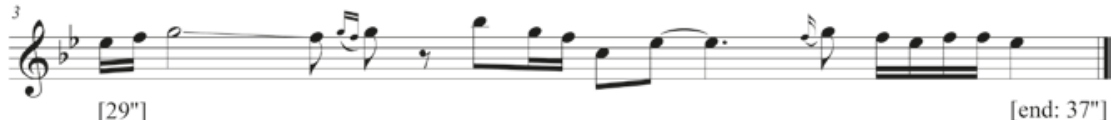

MUSiC TRANSCRiption tr 9 Pileuleuyan played on kumbang flute by Karamaén, 5 June 2014. $<\mathrm{AV} 21>$

analysis), the musicians themselves did not differentiate between grace notes, or musical ornaments and notes of the melody. The 'ornaments' that I transcribed were in Western terms: appoggiatura or note of complement, double appoggiatura, shakes or trills (pitch vibratos: 'tr' in the transcriptions), mordents, and 
Kumbang flute: Piece 1 by Sarjai 1976
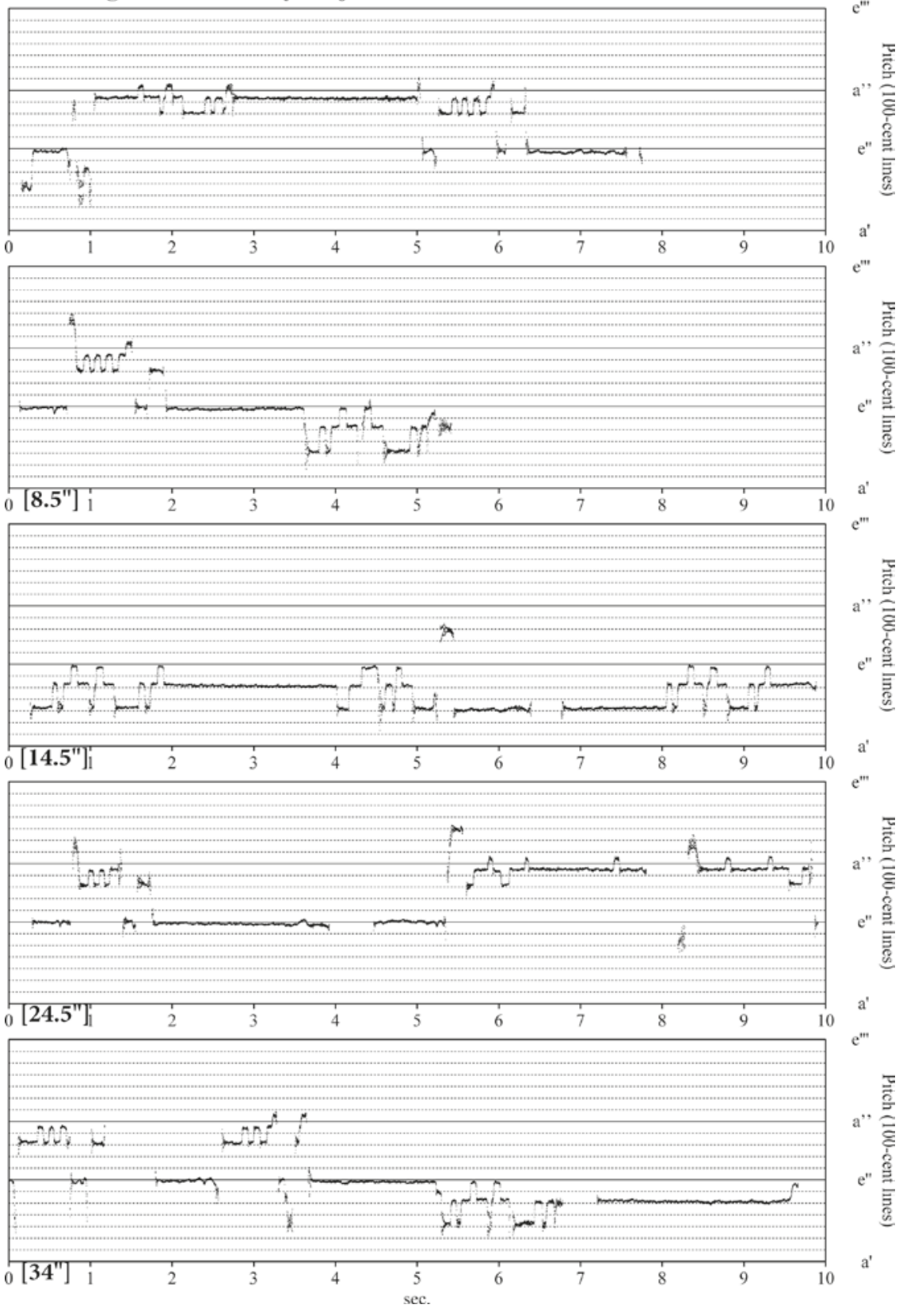

MUSIC TRANSCRIPTION TR 10 PRAAT picture of piece 1 played on kumbang flute by Sarjai, Gajéboh, 20 July 1976. <AV22> 


\section{Kumbang piece 1 - 1976}

(Suling kumbang played by Sarjai)
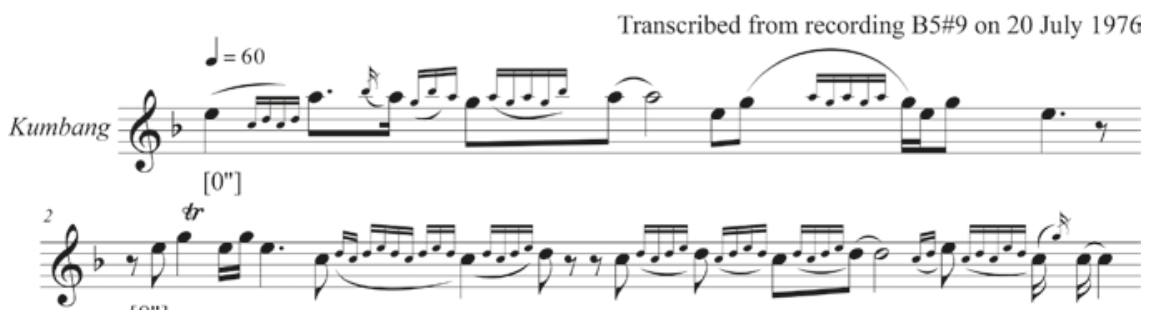

[8"]
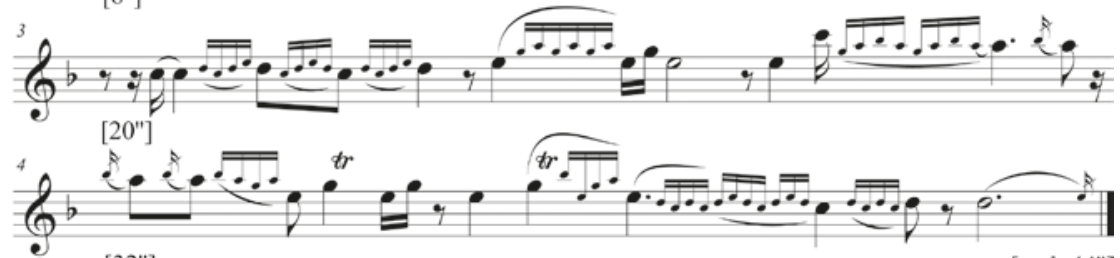

[32"]

[end: 44"]

MUSIC TRANSCRIPTION TR 11 Kumbang piece 1 played by Sarjai, 20 July 1976; see also Music Transcription Tr 10. Listen to $<\mathrm{AV} 22>$

turns. Further, Karamaén used glissando: that is, gliding from a note to another one by relatively slowly opening or closing a finger hole. Almost all players of the different Baduy flutes used glissando, but only from a higher to a lower note, indicated by a declining line, and not from a lower to a higher note.

In contrast to Karamaén, Sarjai did not give names to the three pieces he played on his suling kumbang. His style is different from Karamaén's playing in June 2014. For instance, Sarjai played trills on several notes, which was not done by Karamaén. On the whole Karamaén played less ornaments than Sarjai. Both kumbang players used much more musical ornamentations than, for instance, the voices in Music Transcription $\operatorname{Tr} 7$ of Kapergok. In Section 7.3 I already remarked that one reason will be that the text of the susualan is important and using many musical ornaments may obscure the text.

\subsection{Tarawélét Flute}

Like the suling kumbang, the tarawélét, also called tarawélot or taléot, is a transverse or side-blown flute with two finger holes. ${ }^{4}$ However, unlike the suling

4 There is not much standardization of terminology. The taléot is also described as an ocarina (earthenware wind instrument) in the Banjaran region and other parts of west Java; like the 
kumbang, both finger holes of the tarawélét are close together and near the open end of the flute. I have three tarawélét, one obtained in July 1979 from the village secretary Ukang Sukarna (A1979: 2), the second was given to me by jaro Asrab on 6 November 1992 (A1992-2: 17), and the last one was obtained in June 2014. According to jaro Asrab the second instrument came from the puun of Cikartawana and it was made of tamiang bamboo. The last one was made by Karamaén. He used buluh (or wuluh) bamboo for the flute, which is slightly thicker than the tamiang bamboo used for the suling kumbang. The position of the holes in the flute were also expressed in rumbak units, the circumference of the flute cylinder near the mouth hole. A tarawélét should be about 5 rumbak long, according to Karamaén. The first finger hole should be about one rumbak from the open end of the tarawélét and the distance between the two finger holes should be about $1 / 2$ rumbak. My three flutes (Figure 52 ) are slightly longer than 5 rumbak: 5.7, 5.8 and 6.5 rumbak. The lowest hole is respectively o.9, 1.1 and 1.2 rumbak from the open end and the distance between the two finger holes is, in the same order, o.5, 0.7 and o.6 rumbak. I interpret these measurements, presented in Table 20, as more or less confirming what Karamaén said.

Note that the inner diameter of the three tarawelét is between 2.0 and $2.5 \mathrm{~cm}$, which is larger than the $1.7 \mathrm{~cm}$ inner diameter of the suling lamus and suling kumbang. Further, the tarawelét are shorter than the kumbang. As discussed above, this affects the ratio given in the last row of Table 20 , and practically it means that the tarawélét can produce the fundamentals in the lowest octave, this in contrast to the kumbang.

The notes played by Karamaén on the in 2014 recorded tarawélét 2014R and the approximation in staff notation are presented in Table 21. On this tarawélét 2014R the three basic notes are about: e (ca. 33 o Hertz), f\# and a- (somewhat less than $440 \mathrm{Hertz}$ ). In the second octave these notes e, $\mathrm{f}$ and a- are repeated an octave higher (first overtones), and two higher notes $\mathrm{b}$ and c\# are added by blowing more fiercely and producing the second overtone of $\mathrm{e}^{1}$ and $\mathrm{f}^{1}$ (both about one fifth higher than the first overtone). This is similar on the other three tarawélét listed in Table 21. The tarawélét all have three notes in the lowest octave and five notes in the higher octave, consisting of the first and second

elét it is played by boys herding cattle or keeping the birds away from the rice fields (Ensiklopedi Sunda 2000; see also Kunst 1973: 375 and Soepandi 1995b: 198). Budi (2015: 134) gives the name toléat for 'a wind instrument made of tamiang bamboo' in Ciptagelar. Masunah et al (2003-1:15) describe a toléat and give a photograph showing an end-blown flute with 7 finger holes, very similar to the elét. On the website http://www.auralarchipelago.com/auralarchipelago/toleat [visit 4 December 2018] another toléat is played and described as 'a kind of single reed bamboo instrument' in the Subang region. This is definitely different from the Baduy taléot/tarawélét that does not use a reed. 
TABLE 20 Measurements of three tarawélét flutes in cm

\begin{tabular}{|c|c|c|c|}
\hline $\begin{array}{l}\text { Year in which the tarawélét } \\
\text { was obtained }\end{array}$ & 1979 & 1992 & $\begin{array}{l}2014 \mathrm{NR}(\text { not } \\
\text { recorded) }\end{array}$ \\
\hline
\end{tabular}

Total length of flute 44.8

$49 \cdot 0$

58.0

Length from partition to open

43.8

48.0

$57 \cdot 3$

end (inside measurement)

(5.8 rumbak)

(5.7 rumbak)

(6.5 rumbak)

Width of partition + end piece 1.0

1.0

0.7

Outer diameter at about $5 \mathrm{~cm}$

2.4

$2.4-2.55$

2.8

from partition, almost at the

position of the mouth hole

1 rumbak

Outer diameter at about $5 \mathrm{~cm}$

from the open end of flute

Inner diameter at the open

end of the flute

Second finger hole (farthest

from mouth hole)

Lower edge, position from

open end

Upper edge, position from

open end

Diameter finger hole

Distance to first finger hole (lower edges)

First finger hole (nearest to mouth hole)

Lower edge, position from

open end

Upper edge, position from

open end

Diameter finger hole

Distance to mouth hole

(lower edges)

Distance lower edge to partition

Mouth hole

Lower edge, position from

open end

\section{$7 \cdot 5$}

$2.4-2.5$

2.0

8.4

8.8

$2.3^{-2.55}$

$2.9-3.0$

7.8

(1.1 rumbak)

8.5

$7 \cdot 9$

(o.9 rumbak)

10.2

8.8

(1.2 rumbak)

11.1

$0.6-0.7$

0.7

0.8

4.7

(0.7 rumbak)

3.8

( 0.5 rumbak)

$5 \cdot 4$

(o.6 rumbak)
11.8

12.5

0.6-0.7

28.3

$27 \cdot 3$

(3.8 rumbak)

40.8

$45 \cdot 1$

12.4

13.2

0.6

32.6

35.2
15.6

16.4

$0.7-0.8$

37.6

41.7

(4.2 rumbak)

(4.7 rumbak)

53.2 
TABLE 20 Measurements of three tarawélét flutes in cm (cont.)

\begin{tabular}{llll}
\hline $\begin{array}{l}\text { Year in which the tarawélét } \\
\text { was obtained }\end{array}$ & 1979 & 1992 & $\begin{array}{l}\text { 2014NR (not } \\
\text { recorded) }\end{array}$ \\
\hline $\begin{array}{l}\text { Upper edge, position from } \\
\text { open end }\end{array}$ & 42.1 & 48.4 & 54.7 \\
$\quad \begin{array}{l}\text { Diameter mouth hole } \\
\begin{array}{l}\text { Distance to partition (lower } \\
\text { edges) }\end{array}\end{array}$ & $\begin{array}{l}1.0-1.3 \\
\text { Ratio (length from }\end{array}$ & $0.7-1.4$ & $1.1-1.5$ \\
\begin{tabular}{l} 
partition: inner diameter) \\
\hline
\end{tabular} & 21.9 & 2.7 & 4.3 \\
\hline
\end{tabular}

overtones of the three notes in the lowest octave. The three tarawélét listed in Table 20 and the recorded one in $2014(2014 \mathrm{R})$ produce approximately the notes listed in Table 21 and we may consider this to be saléndro tone systems. In the Table $\mathrm{M}$ indicates the mouth hole, $\mathrm{O}$ is an open finger hole and $\bullet$ a closed finger hole, like used for the kumbang in Table 18.

On 5 June 2014 Karamaén played three tarawélét pieces that I recorded on audio and video. These are the only three pieces for tarawélét that I recorded during my fieldwork. The songs were called Noong Rangda ('To drop in at the widow'), Keupat Reundang ('To sway one's arms when happy') and Rangda Ngeukeupan ('The widow throws her arms around him'). He told that these three songs were handed down from the ancestors, and that there were no other melodies (lagu) for the tarawélét. In each of the three tangtu villages (Cibéo, Cikartawana and Cikeusik) they used this repertoire; see interview on film 2014-2: 39'. See also remarks about the song titles in Section 7.1.

From film recording $<\mathrm{AV}_{23}>$ and transcription $\operatorname{Tr} 12$ it may be heard and seen that Karamaén started Noong Rangda in the lowest octave with only the three notes $\mathrm{e}-\mathrm{f} \#-\mathrm{a}$ (first line) and then moved to the second octave, in which five tones can be played. From there on he stayed in this second octave emphasizing the notes a, e and f\#. The ornamentation mainly consists of appoggiaturas and upper and lower mordents. However, in the third and last line we find runs of three grace notes $(e-f \#-a)$. In the last line these ornaments are sometimes extended with a repeat of the two last grace notes $(\mathrm{e}-\mathrm{f} \#-\mathrm{a}-\mathrm{f} \#-\mathrm{a})$ or a repeat of the first two notes of this run $(\mathrm{e}-\mathrm{f} \#-\mathrm{e}-\mathrm{f} \#-\mathrm{a})$. These ornamentations are close to the physical possibilities on the flute: e (produced $\mathrm{M} \bullet \bullet), \mathrm{f} \#$ 
TABLE 21 Approximate Western notes produced by the three tarawélét listed in Table 20

In the second column the length of the tube is given; the notes are rounded to the nearest semitone

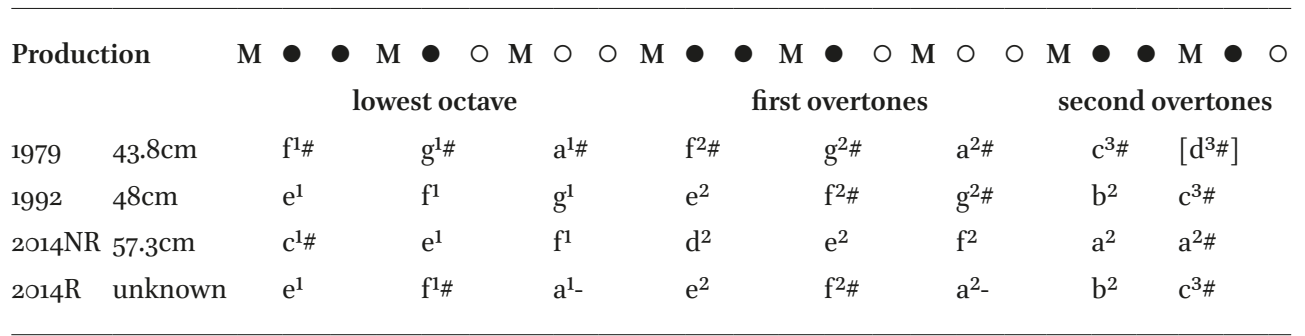

\section{Noong Rangda}

(Tarawélét flute played by Karamaén)

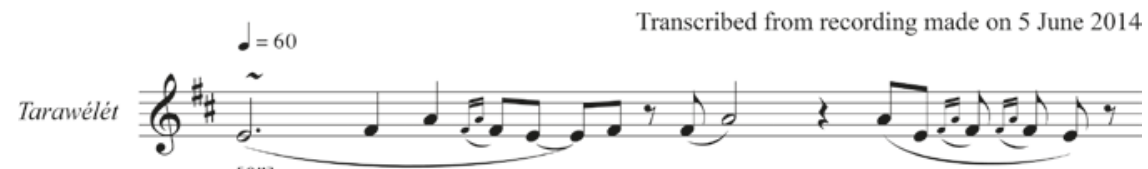

$\left[0^{\prime \prime}\right]$

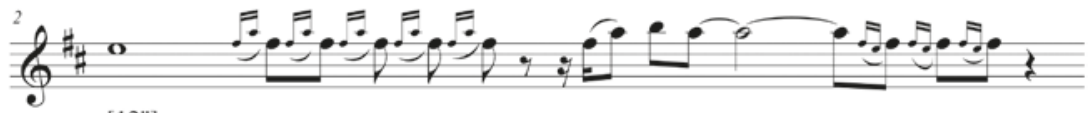

[12"]

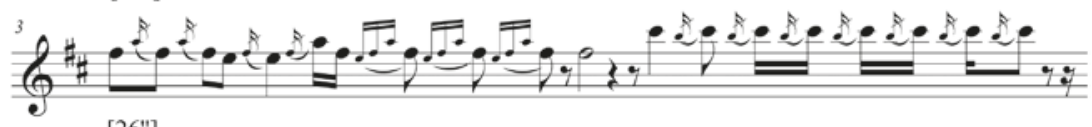

$\left[26^{\prime \prime}\right]$

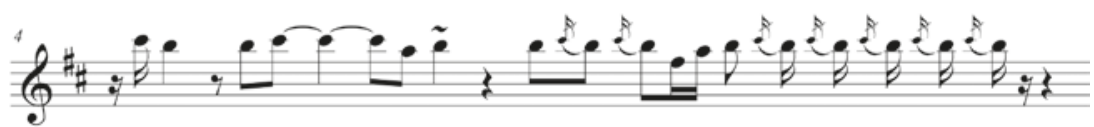

[39"]

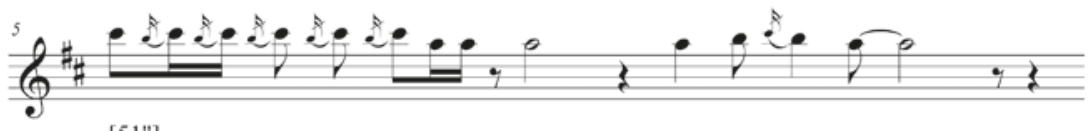

[51"]

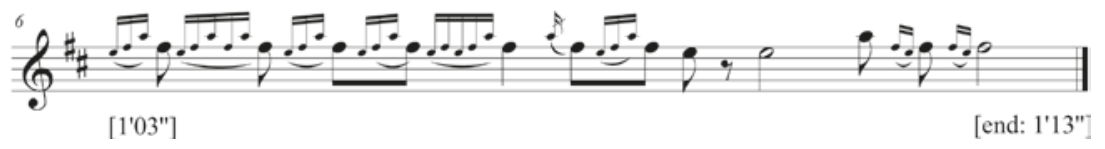

MUSIC TRANSCRIPTION TR 12 Noong Rangda played on tarawélét flute by Karamaén, 5 June 2014. Listen to <AV23> 
(produced $\mathrm{M} \bullet \mathrm{O}$ ) and a (produced $\mathrm{M} \bigcirc \mathrm{O}$ ). In the other two melodies played by Karamaén, Keupat Reundang and Rangda Ngeukeupan, he started immediately in the second octave and the three notes in the lowest octave were not used at all. Further the ornaments in these two melodies very much resemble those in the transcribed Noong Rangda melody.

\subsection{Lamus Flute and Elét}

The end-blown and six-finger hole suling lamus, the 'bellows flute', presumably got this name because its player uses the circular breathing technique: a constant flow of air is blown into the flute and the sound does not stop while the player is breathing. The Ensiklopedi Sunda (2000) mentions under lamus that the circular breathing technique takes a long time to master and that some people think it may have negative health effects: players may get bad teeth, sunken cheeks and hernia. The circular breathing technique is also used when playing the Minangkabau saluang flute in West Sumatra. In 1996 staff of the conservatory in Padang Panjang told me that it took their music students at least three months to master this technique.

The lamus flute is very similar to the ring flutes as used in the Cianjuran and gamelan degung ensembles of west Java, but today the flutes in these ensembles are not blown with the circular breathing technique. Brandts Buys and Brandts Buys-Van Zijp (1926: 57-58) discuss the playing of a 6-finger hole endblown Sundanese suling by a player in the 1920s, who was working on a kina estate south of Bandung, on the Péngaléngan plain, but originated from Garut. This player also used the circular breathing technique and Brandts Buys and his wife mention that they had not seen this circular breathing technique used for the Sundanese and Javanese suling before.

The length of the Baduy lamus is about $60 \mathrm{~cm}$. Most Baduy players close the highest three finger holes (near the mouth piece) with forefinger, middle finger and ring finger of the left hand and the lowest three holes may be closed by the same fingers of the right hand. This is also the most common way of using left and right hand in other parts of west Java (Van Zanten 1989: 101). Ayah Hamdan from Kadujangkung did it the other way around: he closed the highest finger holes with his right hand and the lower three with his left hand (A1992-1: 56 , photograph). ${ }^{5}$ As the lamus is very much like the

5 See Spennemann 1984 for general remarks about right- and left-handedness in the pictures on the Borobudur. 
flutes most common in Sunda, I will refer to the description I gave for a $62 \mathrm{~cm}$ long suling as used in Cianjuran and the $37 \mathrm{~cm}$ long suling degung in Van Zanten (1989: 99-105) and this section only presents a few characteristics of the Baduy lamus.

The lamus is made of tamiang bamboo, like most bamboo flutes in west Java. In July 1976 I followed and filmed Péi from Kompol to find pieces of bamboo for making suling lamus and elét. He said that the bamboo should still be greenish at the time of cutting the pieces. Then the bamboo should dry in the sun during daytime and taken inside during the night for one to one-and-ahalf month, before you could start making the flutes. The mouthpiece of the suling lamus is made at a partition of the bamboo and the duct for the air flow is closed with a ring made of the dry leaf of the coconut palm tree (daun kalapa paéh). This 'ring' is called syiwér (Péi, Kompol 1976), or siwér (Hamdan, Kadujangkung 1992; Nasinah, Gajéboh 2003; Sardi, dangka hamlet Cikarého near Kompol, 2014); sumber in other parts of Sunda.

In July 1976 Péi used the outer circumference of the bamboo tube as a unit for the measurements of the suling lamus. In October 1992 Hamdan from Kadujangkung and in May 2014 Sardi from Kompol also explained that the outer circumference (beulitan, b) was the basis: the total length of the lamus should be $81 / 2$ times the circumference. However, Péi and Sardi used slightly different distances for the top part of the flute, that is, from the highest hole to the mouth hole: for this Péi took a distance of four times the circumference, and Sardi said it should be five times this circumference. ${ }^{6}$ The circumference of the lamus that I possess (see Figure $5^{2}$ and Table 23 below) is $6.6 \mathrm{~cm}$, and the distance of the highest finger hole (liang) to the mouth piece is about $28 \mathrm{~cm}$, or $4.2 \mathrm{x}$ circumference. Hence this is closer to what Péi said, and that holds also for the Baduy flute played by Narse from Nagrék (photo in Van Zanten 1989: 108) and Yati from Gajéboh (photo in Van Zanten 1995: 524). According to Péi the lowest finger hole should be a distance of about $1 \frac{1}{2} \mathrm{~b}$ from the lower end of the flute. The next two holes should be on consecutive distances of $1 / 2 b$; the lowest of the next three holes should be $1 b$ closer to the mouth hole and the holes should be $1 / 2 \mathrm{~b}$ apart. See the scheme in Table 22 below.

In 1976 I obtained a suling lamus in Gajéboh, probably from the player Yati or Narse. See Table 23 below for its measurements. This flute is about $62 \mathrm{~cm}$ long, like the flute used for Cianjuran music in Van Zanten (1989: 98, Figure 4).

6 On 26 May 2014 I took a photograph of Sardi's not yet finished suling lamus, to be used by himself, and here this distance was indeed taken close to five times the circumference. 
TABLE 22 Péi's scheme for finger holes in units b (circumference) and relation to length of lamus flute $\left(8^{1 / 2} \mathrm{~b}\right)$

\begin{tabular}{|c|c|c|c|c|c|c|c|c|c|c|}
\hline \multirow[t]{2}{*}{$\mathbf{M}$} & & & & 0 & 0 & 0 & 0 & 0 & 0 & \\
\hline & 1 & 2 & 3 & 4 & $4^{1 / 2}$ & 5 & 6 & $61 / 2$ & 7 & $8^{1 / 2}$ \\
\hline
\end{tabular}

\section{In units of According to circumference scheme Péi}

\begin{tabular}{|c|c|c|c|}
\hline \multirow{2}{*}{$\begin{array}{l}\text { Year in which the suling } \\
\text { lamus was obtained } \\
\text { Obtained from }\end{array}$} & \multicolumn{3}{|l|}{ July 1976} \\
\hline & $\begin{array}{l}\text { Yati, Narse? } \\
\text { (Gajéboh) }\end{array}$ & & \\
\hline Total length of flute & 62 & 9.4 & $8^{1 / 2}$ \\
\hline $\begin{array}{l}\text { Outer diameter near blowing } \\
\text { end }\end{array}$ & 2.1 & & \\
\hline Outer diameter lower end & 2.2 & & \\
\hline $\begin{array}{l}\text { Circumference (beulitan, } \\
\text { b) near blowing end }\end{array}$ & $\begin{array}{l}2.1 \mathrm{x} \\
\pi=6.6 \mathrm{~cm}\end{array}$ & & \\
\hline $\begin{array}{l}\text { Inner diameter of the flute at } \\
\text { lower end }\end{array}$ & 1.7 & & \\
\hline Diameter of each finger hole & $0.5^{-0.6}$ & & \\
\hline Position upper part finger & & & \\
\hline $\begin{array}{l}\text { holes from lower end of flute } \\
\text { sixth finger hole (farthest } \\
\text { from mouth hole) }\end{array}$ & 10.9 & 1.7 & 1.5 \\
\hline fifth finger hole & 14.5 & 2.2 & 2 \\
\hline fourth finger hole & 18.1 & 2.7 & 2.5 \\
\hline third finger hole & $25 \cdot 1$ & 3.8 & 3.5 \\
\hline second finger hole & 28.5 & $4 \cdot 3$ & 4 \\
\hline first finger hole & 32.3 & 4.9 & 4.5 \\
\hline $\begin{array}{l}\text { Distance upper part first } \\
\text { finger hole from partition }\end{array}$ & 28.0 & 4.2 & 4 \\
\hline
\end{tabular}




$\begin{array}{lll}\text { Mouth lefthand } & / \quad \text { right hand } & \text { Approximate } \\ \text { hole } & & \\ & & \text { Western note } \\ \text { (PRAAT analysis) }\end{array}$

\begin{tabular}{lllllllll}
\hline $\mathrm{M}$ & 0 & $\bullet$ & 0 & $/$ & 0 & 0 & 0 & $\mathrm{c}^{2 \#}$ \\
$\mathrm{M}$ & $\bullet$ & $\bullet$ & 0 & $/$ & 0 & 0 & 0 & $\mathrm{a}^{1 \#}$ \\
$\mathrm{M}$ & $\bullet$ & $\bullet$ & $\bullet$ & $/$ & 0 & 0 & 0 & $\mathrm{~g}^{1 \#}$ \\
$\mathrm{M}$ & $\bullet$ & $\bullet$ & $\bullet$ & $/$ & $\bullet$ & $\bullet$ & 0 & $\mathrm{f}^{1}$ \\
$\mathrm{M}$ & $\bullet$ & $\bullet$ & $\bullet$ & $/$ & $\bullet$ & $\bullet$ & $\bullet$ & $\mathrm{d}^{1} \#$
\end{tabular}

The finger holes of this suling lamus are slightly more spread than the finger holes of the Cianjuran flute, otherwise the two flutes are very similar; this is also clear from Photo 20 in Van Zanten (1989: 100), where this suling lamus is included.

From Table 22 and the last two columns in Table 23 it follows that this lamus is close to the measurements that Péi gave for the total length and position of the finger holes, expressed in the circumference of the flute near the mouth hole (b). It seems that most Baduy players make their own lamus, but some prefer to buy a flute from a person who is known to make good flutes.

On film $<\mathrm{AV}_{24}>$ it may be seen that Nasinah from Gajéboh used the fingersettings for producing the different notes of the (approximate) saléndro system, as presented in Table 24 .

Other Baduy lamus players used a similar system. The lamus player Ojél, from Kadujangkung, did not move the middle fingers, but just lifted the index and ring finger of both hands to produce different notes on 17 October 1992. That is, he did the same as Nasinah, except for the middle note ( $\mathrm{g}^{1} \#$ of the scheme), for which Ojél also closed the second hole from the bottom. This is fairly similar to what Cianjuran flutists do: the closing of the middle hole for each hand by Nasinah and Ojél is a small adjustment to the frequency of the 'Cianjuran tones' (see Van Zanten 1989: 127).

Music Transcription $\operatorname{Tr} 13$ represents the song Kembang Beureum (Red Flower) played on the lamus by Yati from Gajéboh. The recording dates from 19 July 1976 and was made in Gajéboh. In the transcription I used the following notes from low to high for Yati's playing: $\mathrm{c}^{1}, \mathrm{~d}^{1}, \mathrm{f}^{1}, \mathrm{~g}^{1}, \mathrm{~b}^{1}-\mathrm{flat} \mathrm{c}^{2}, \mathrm{~d}^{2}, \mathrm{f}^{2}$. 


\section{Kembang Beureum}

Lamus flute played by Yati - 1976

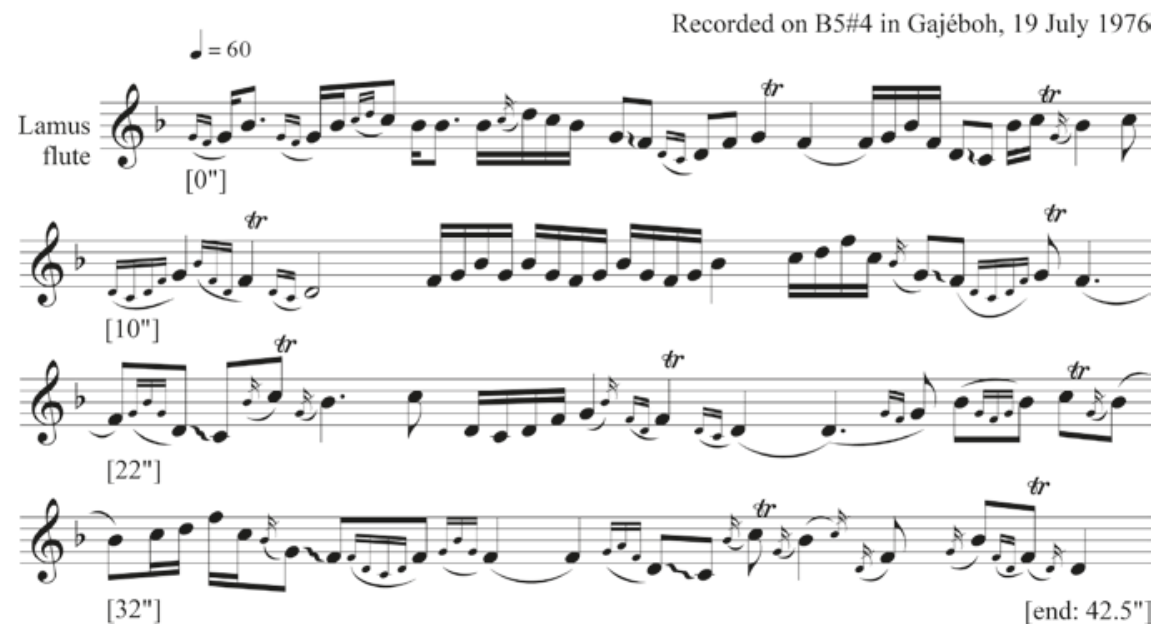

MUSIC TRANSCRIPTION TR 13 Kembang Beureum played by Yati on suling lamus, Gajéboh, 19 July 1976. Listen to <AV25>

To me the Baduy lamus sounds 'darker' than the Cianjuran flutes. The limited range of notes used may be one of the reasons for this: in the above transcription the highest note is $\mathrm{f}^{2}$ and the lowest one $\mathrm{d}^{1}$. This is a relatively small range that does not include the highest possible notes, but I also think that the 'dark' sound may be caused by organological factors. This needs further investigation. When we compare our transcription of the lamus song Kembang Beureum with the three transcriptions that Brandts Buys and Brandts Buys-van Zijp made in Garut (1926) we may see some similar ornaments like shakes, lower mordents, turns and glissando. I will not further discuss these issues here, as it falls outside the scope of this book.

\subsubsection{Elét}

The elét is an end-blown flute, $15^{-20} \mathrm{~cm}$ long with five finger holes. It is only played by Outer Baduy boys and men and, like the lamus, with the circular breathing technique. Apparently the circular breathing technique is not immediately mastered when learning to play the elét: in a sound film made $26 \mathrm{July}$ 1976 I recorded a boy of about 14 years old (son of Péi?), who played the elét by regularly taking a short break for breathing. The elét type of flute is called bangsing in other parts of west Java. Soepandi and Atmadibrata (1977: 9) and Soepandi (1995b: 64) describe the elét as a 'vertical flute in Banten with three 
(finger) holes'. Soepandi (1995b:18) states that the Baduy have an 'elét with two and a tarawélét with three (finger) holes'. Presumably this is a mistake. The only Baduy elét that I saw and recorded have five finger holes and the tarawélét, discussed in Section 8.2 above, only have two finger holes. One of the problems is also that there is little standardization of terminology for Sundanese music in different regions. See also my remarks about the variety of meanings for the toléat and taléot musical instruments in Section 8.2.

Some Baduy (Péi in 1976, Usman A1992-1: 30, Sardi A2014-1: 10) were of the opinion that the elét cannot be played inside the house or even not in the hamlet; the best place to play would be the open field. This is partially because the elét is associated with herding buffalo or goat and these animals are not allowed inside the Baduy area (compare also the buffalo materials used in knives of the Outer Baduy in Section 2.7). Sardi added that whistling without an instrument (ngahéot) should also not be done inside the house. Others, like Nasinah from Gajéboh, whom I recorded in 2003, were less strict and of the opinion that you were allowed to play the elét on the veranda of the house, be it not for 'too long'. Hence I could record Nasinah playing the elét on his veranda in Gajéboh (see film $<A V_{24}>$ ). Sardi from dangka hamlet Cikarého near Kompol contrasted the atmosphere of playing elét and suling lamus by saying that the elét was good for playing in daytime and the suling lamus better for playing during the evenings, when it was quiet. This opposition between daytime and the cooler night that is better for contemplation while making music is a fairly common idea in west Java; see also Van Zanten (1989: 1, 94).

In July 1976 I obtained an elét that had just been made by Péi in Kompol and in March 2003 I bought an elét made by Nasinah in Gajéboh. In July 1976 I filmed Péi making a suling lamus and two elét. The piece of bamboo (awi apus $=(\text { Ind.) bambu tali })^{7}$ used for the elét is such that there is a partition in the bamboo at the lower end of the flute, that is partially opened when making the flute. The upper end of the bamboo is initially open and used for making the mouth hole with a stop, that is, a separate piece of wood filling most of this open tube and leaving only the duct for blowing air into the flute (like in the Western recorder).

Péi explained that the length of the elét, without the top ring with the duct, should be such that, when taking the flute in your hand, it should reach from the palm to the end of your stretched thumb, that is, about $15 \mathrm{~cm} .{ }^{8}$ For

7 Gigantochloa apus (Bl. Ex Schult.f.) Kurz, Sastrapradja et al. 1977: 50-51.

8 This seem to conflict with other information: the elét should be about $20 \mathrm{~cm}$ long, that is, the distance between tops of thumb and little finger when spread as much as possible. This distance is called one jeungkal: sajeungkal. 
the suling lamus Péi used the circumference of the tube of bamboo as a unit of measurement, like Karamaén had explained for the suling kumbang and tarawelét (see above: Karamaén called this length one rumbak). However, for the elét Péi used the width of his index just below the nail as unit, that is, about 1.7-1.8 cm between the holes. The distance between the finger holes should be one such unit + width of one finger hole, and the upper part of the first (top) finger hole should be about 2 units from the ring with the duct. The total length of the elét below the top ring with the duct should be about 6.5 units + the space for 5 finger holes. This is about right for the two elét, given in Table 25 below.

While playing, both Péi in 1976 and Nasinah in 2003 closed the three highest holes (near to the mouth hole) with the forefinger (f), middle finger $(\mathrm{m})$ and ring finger ( $\mathrm{r}$ ) of the left hand ( $\mathrm{LH}$ ). The lowest two holes were closed by index and middle finger of the right hand (RH). This was also done by the boy (Péi's son?) that I filmed playing the elét in July 1976. Péi told that in general only the four lowest holes are used when playing and that the highest hole remains closed. The production of the notes is presented in the scheme in Table 26. Like before, in the used outline of the elét, $\mathrm{M}$ indicates the mouth hole, $\mathrm{O}$ is an open finger hole and $\bullet$ a closed finger hole.

In $<\mathrm{AV}_{24}>$ you may see and hear Nasinah from Gajéboh playing both the lamus and the elét and the circular breathing he used in 2003. The long notes are used for breathing. Although generally many grace notes and other ornaments are used in the elét music, there also is the influence of the individual player. Nasinah's playing in 2003 was less virtuoso than Yati's elét playing and also than Péi's playing in 1976 to be discussed now.

Music Transcription $\operatorname{Tr} 14$ is taken from a recording of an elét played by Péi at his house in Kompol on 25 July 1976 (AV26>). I took the notes in the transcription about one semitone higher than those given in Table 26 to avoid the many accidentals (\#), that is, from low to high: $a^{2}, c^{3}, d^{3}, f^{3}, g^{3}, a^{3}, c^{4}$, $\mathrm{d}^{4}$. This elét range of notes lies about two octaves higher than the range of notes on the lamus. The transcribed piece is Tumpak Sadok ("To drive in a two-wheeled, horse-drawn carriage') from tape $\mathrm{B}_{5}$, \#20. As compared with the other Baduy flute playing this elét playing is more ornamented. Moreover, Péi regularly uses glissando: gliding from one note to another by relatively slowly opening or closing a finger hole. Péi only used glissando from a higher to a lower note, like the other Baduy flute players. ${ }^{9}$ With the many

9 See the undulating declining line, for instance in the sections between 22 " and 23 " (note $\mathrm{a}^{3}$ to note $\mathrm{f}^{3}$ ) and between 57 "and $58^{\prime \prime}$ (note $\mathrm{g}^{3}$ to note $\mathrm{d}^{3}$ ) after the start. 
TABLE 25 Measurements of elét flutes in $\mathrm{cm}$

\begin{tabular}{|c|c|c|}
\hline Year in which the elét was obtained & July 1976 & March 2003 \\
\hline Obtained from & Péi (Kompol) & $\begin{array}{l}\text { Nasinah } \\
\text { (Gajéboh) }\end{array}$ \\
\hline Used for tube & Awiapus & Awi \\
\hline $\begin{array}{l}\text { Used wood for stopping the flute at the } \\
\text { blowing end }\end{array}$ & $\begin{array}{l}\text { Harendong (or } \\
\text { jengjeng?) }\end{array}$ & Jénkol \\
\hline Total length of flute & $15 \cdot 9$ & 18.5 \\
\hline $\begin{array}{l}\text { Outer diameter original piece of bamboo } \\
\text { near blowing end }\end{array}$ & 1.7 & 2.7 \\
\hline Inner diameter of the flute & 1.2 & 1.9 \\
\hline Length of bamboo ring for mouthpiece & 1.6 & 2.4 \\
\hline $\begin{array}{l}\text { Length from stop in ring to open end } \\
\text { (inside measurement) }\end{array}$ & 14.1 & $15 \cdot 9$ \\
\hline Lower part mouth hole from bottom end & $13 \cdot 9$ & $15 \cdot 3$ \\
\hline Outer diameter tube near hole at the back & 1.5 & 2.2 \\
\hline $\begin{array}{l}\text { Outer diameter at about } 2 \mathrm{~cm} \text { from the } \\
\text { lower end of flute }\end{array}$ & 1.4 & 2.1 \\
\hline $\begin{array}{l}\text { Diameter of hole made in partition at lower } \\
\text { end }\end{array}$ & 0.5 & 0.5 \\
\hline Diameter five finger holes & 0.2 & 0.5 \\
\hline \multicolumn{3}{|l|}{$\begin{array}{l}\text { Position upper part finger holes from lower } \\
\text { end }\end{array}$} \\
\hline fifth finger hole (farthest from mouth hole) & 1.8 & 2.0 \\
\hline fourth finger hole & 4.0 & 4.4 \\
\hline third finger hole & 6.3 & 6.9 \\
\hline second finger hole & 8.5 & 9.6 \\
\hline first finger hole & 10.6 & 12.3 \\
\hline
\end{tabular}

fast ornaments in this music, I have sometimes used 1/64 notes (with three 'flags') in the transcription, instead of small grace notes. The piece starts and ends on the note $\mathrm{d}^{3}$ that is produced by closing the upper three holes. The long notes are mostly $\mathrm{d}^{3}$ and the higher fifth $\mathrm{a}^{3}$. This is another example of the fifth-relationship in Sundanese music (compare for Cianjuran also Van Zanten 1989: Chapter 7). 
Production of tones on elét

Produced tone in nearest

Western semitone

Péi (1976) Nasinah (2003)

Mouth piece Finger holes

Left hand (highest) Right hand

\begin{tabular}{|c|c|c|c|c|c|c|c|}
\hline & $\mathrm{f}$ & $\mathrm{m}$ & $r$ & $\mathrm{f}$ & $\mathrm{m}$ & & \\
\hline $\mathrm{M}$ & • & - & $\bullet$ & - & • & $\mathrm{g}^{2 \#}$ & $\mathrm{f}^{2} \#$ \\
\hline $\mathrm{M}$ & • & • & $\bullet$ & • & 0 & $\mathrm{~b}^{2}$ & $\mathrm{~g}^{2 \#}$ \\
\hline M & • & - & • & O & 0 & $c^{3 \#}$ & $a^{2} \#$ \\
\hline $\mathrm{M}$ & • & • & 0 & 0 & 0 & $\mathrm{e}^{3}$ & $c^{3}$ \\
\hline M & • & 0 & 0 & 0 & 0 & $\mathrm{f}^{3} \#$ & $\mathrm{~d}^{3} \#$ \\
\hline $\mathrm{M}$ & 0 & 0 & 0 & 0 & 0 & $\mathrm{~g}^{3} \#$ & $\mathrm{f}^{3} \#$ \\
\hline M & 0 & O & 0 & • & • & $\mathrm{b}^{3}$ & $\mathrm{~g}^{3} \#$ \\
\hline M & 0 & 0 & 0 & 0 & - & {$\left[c^{4} \#\right]$} & {$\left[\mathrm{a}^{3} \#\right]$} \\
\hline
\end{tabular}

\subsection{String Instruments}

The Outer Baduy play several string instruments: two zithers, kacapi pantun and the flat (kacapi) siter, and two bowed lutes, the two-string rendo and the four-string viol that is very similar to the Indian and Western violin. Of these string instruments the Inner Baduy are only allowed to play kacapi pantun. This instrument is used by a pantun storyteller to accompany himself, but also for accompanying other instruments or just playing alone for entertainment.

\subsubsection{Kacapi Pantun}

The Baduy kacapi mentioned in Dutch reports of the 19th century is the $k a$ capi pantun. As far as I know, Van Hoëvell (1845: 428-429) was the first one to describe the kacapi: a 'kind of long guitar, with six equally thick brass strings of unequal length, which are plucked with both hands'. Van Hoëvell also gives a clear drawing of the instruments he described, a kacapi pantun zither and a tarawangsa of the Baduy people he visited. The dictionary of Coolsma (1884) 


\section{Tumpak Sadok}

Elét flute played by Péi,1976
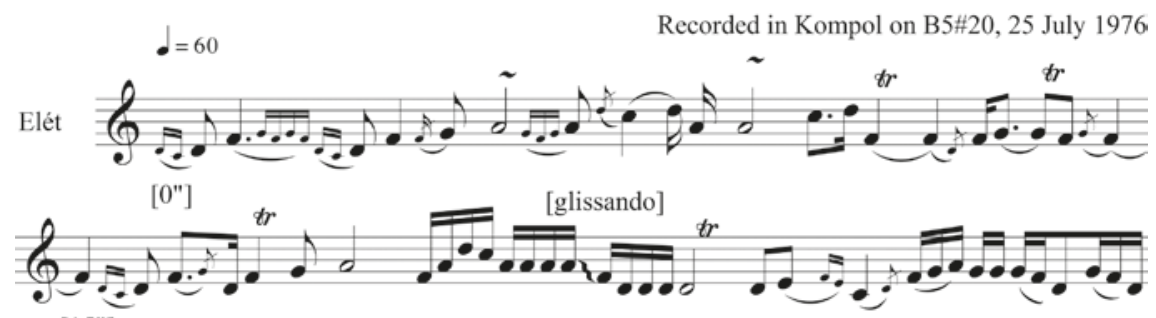

[15"]

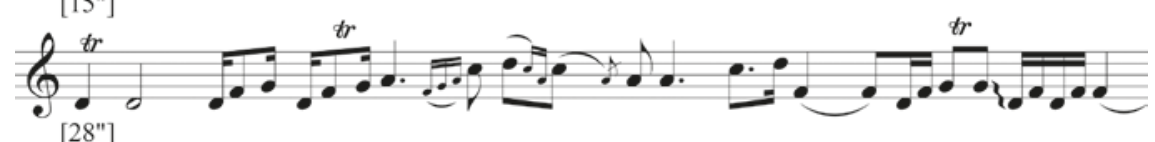

[28"]

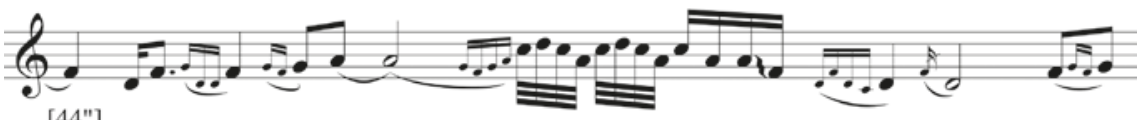

[44"]

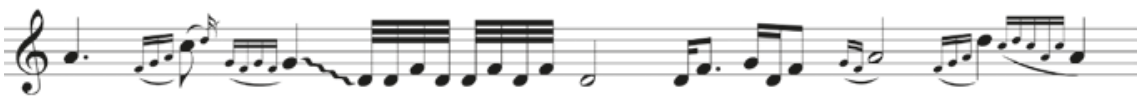

[55"]
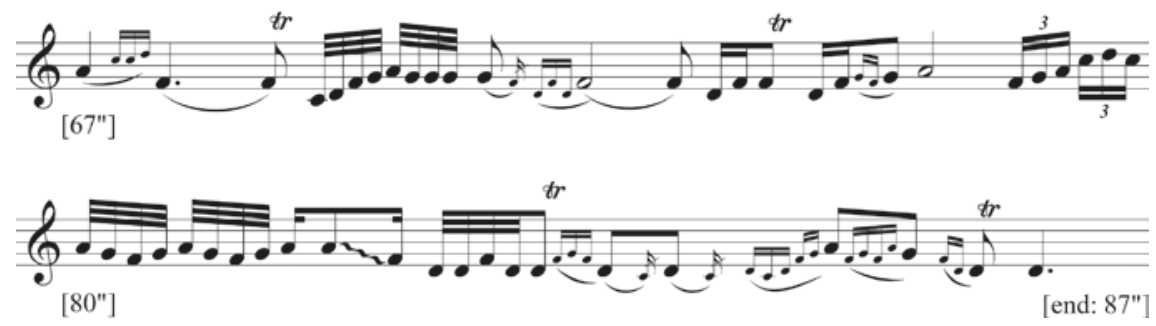

MUSiC TRANSCRIPTION TR 14 Tumpak Sadok played by Péi on elét flute, Kompol, 25 July 1976. Listen to <AV26>

describes the kacapi as a 'kind of lute', generally with six strings, but in some cases with up to fifteen strings. Pleyte (1907b: 26-27) describes the kacapi pantun and tarawangs $a$ and presents drawings of both instruments. According to Pleyte, the older Sundanese bards use kacapi pantun with six or seven brass strings, whereas their younger colleagues increase the number of strings to 11, 14, or 15 so as 'to be able to pluck all songs on the instrument' (see further Van Zanten 1989: 91).

Kacapi pantun and rendo are made from plain white lamé wood; however, compare Section 7.4 and Appendix 4, 1992-o1 Ceuk Arileu stanza 2. The small 
pyramidal-shaped bridges are called susu or inang, words that also mean 'women's breasts'. See for further symbolism of the Sundanese kacapi and its player Van Zanten (1989: 93-98; 2008). In 2003 Satra mentioned that the small bridges (susu) of the kacapi I had just bought in Gajéboh were probably made of karanji (ranji) wood (A2003-1: 51). The wooden tuning pegs (pureut) on the side were made of pinang palm wood. Satra called the supporting beam under the soundboard of the kacapi pantun: palang panguat, crossbeam for strengthening. He also said that the unvarnished lamé wood of the kacapi was sometimes protected against insects by treating it with diesel fuel (solar) mixed with camphor (kapur barus, kamper). Karamaén said that the wooden tuning pegs and small bridges (inang) were made of the strong wood on the outside of the pinang (=jambé) palm: ruyung pinang (A2003-2: 7). Both Satra and Karamaén said that the kacapi pantun strings (kawat) were made of the brake or clutch cables of a motor or bicycle.

Pleyte (1907: 26-27, footnote 1) writes that for pantun accompaniment the Baduy zithers always have 6 strings, according to an elder (kokolot) of Cibéo, who is described as a fairly good kacapi player, and these strings are called (from low to high): 'indung (tuned c\#), bangbrang (f), heuleut (g), bangbrang anak (a), pangadianak (c) and anak (d).'10 As described in Section 6.4 the pantun recitation that I recorded in 1977 was accompanied with an eleven-string kacapi. It seems that for pantun accompaniment the number of zither strings is not very important for present-day Baduy players; however the zither should be a kacapi pantun and not a flat siter.

Baduy use a variety of playing techniques for the kacapi pantun. The pantun performers Arwa from Cicatang in 2013 and also Yanci from Cikadu in 1992 played their kacapi with two index fingers." ${ }^{11}$ The crooked left hand fore finger is used for hitting the lower strings with the nail and the right hand fore finger is used for plucking the higher strings by moving down and slightly towards the player, that is, using the flesh of the finger top. In Tembang Sunda Cianjuran music this hitting with the nail of the forefinger moving away from the player is called the sintreuk technique and plucking towards the player is called the toél technique. It is, for instance, used for the fast runs of the kacapi indung zither (pasieupan and kemprang playing) and the playing of the smaller kacapi rincik zither. However, in Cianjuran the right and left fingers do the opposite of what the Baduy players do: Cianjuran musicians use the sintreuk technique with

10 'De Badoejsche katjapi heeft steeds zes snaren genaamd: indoeng, gestemd: c, kruis bangbrang $f$., heuleut $g$., bangbrang anak $a$., pangadi anak c. en anak $d$, ...' (Pleyte 1907: 26-27).

11 See film 2013-1, 5:44-10:36; film 1992-3, 17:48-33:40; see also the Illustrations 1 and 2 in Van Zanten (2016: 417, 419) and Photos 15, 16, 18, 19 and 24 in Van Zanten (1989: 108) 
the forefinger of the right hand and the forefinger of the left hand pushes the strings with towards the player with the toél technique (Van Zanten 1989: 86, 142, 181).

In 1992 another kacapi pantun player, Saiwin, used an instrument with 13 strings when accompanying a rendo (played by Darmin, later called Daénah) and suling lamus (played by Saléh Rahman). He played with two crooked forefingers and hit the strings with the nails of both the left and the right forefinger. This technique was also applied by Yanci from Cikadu in 1992 when he accompanied Darmin on rendo and a lamus player; see $\left\langle\mathrm{AV}_{27}\right\rangle$.

\subsubsection{Siter and Falsetto Voice}

The flat siter is undoubtedly borrowed from outside Kanékés. It is not made by the Baduy themselves, but bought in the large cities, such as Bandung. On 4 April 2003 and 14 December 2013 I filmed Aki Armad (= Hamdan) from Kadujangkung (films 2003-2, 53:30-58:08; 2013-2, 30:08-33:04) while playing a flat zither (siter) with 20 strings that he had bought in Bandung. For playing he used the forefingers of both hands by plucking the strings moving down and slightly towards the player, called the toél technique in Cianjuran music. On this siter he also used what is called the kait technique for Cianjuran music (Van Zanten 1989: 149-153), that is, using thumb and forefinger of both hands. On 26 March 2003 I recorded Satra (Satrawinata) from Kaduketug on a siter with twenty strings, when he accompanied the female singer Raidah and her husband-violinist Arib from Balimbing (see Section 7.3). Satra only used what is called the kait technique of playing in Cianjuran: forefinger and thumb of both hands and for the lower notes he also occasionally used the middle finger of the left hand, like it is done in Bandung (A2003-1, 42-45, 49-51).

As reported, Baduy zither players rarely accompany their own singing of $s u$ sualan. I only recorded Sawari in 1992 and Sadiman in March 2003, who both accompanied their own singing with zither playing. Sadiman used a twentystring flat zither for this; he did not use a falsetto voice when singing, like Sawari had done in 1992. (Van Zanten 1995: 530; A2003-1: 27, audio MD2003-6). In $<\mathrm{AV}_{31}>$ Sawari may be heard when singing one verse of the song Budak Bagus in falsetto voice and accompanying himself on the kacapi siter in Cipangembar, 12 October 1992; see the text and translation in Appendix 4, item 1992-05.

\subsubsection{Rendo}

Only the Outer Baduy, not the Inner Baduy, have a bowed lute with two strings, called rendo. The bow (pangését) is kept in the right hand and the instrument on the left. The right string, as seen from the player, is used to play a melody. The left string is (only?) used to pluck the last note of a musical phrase on the 


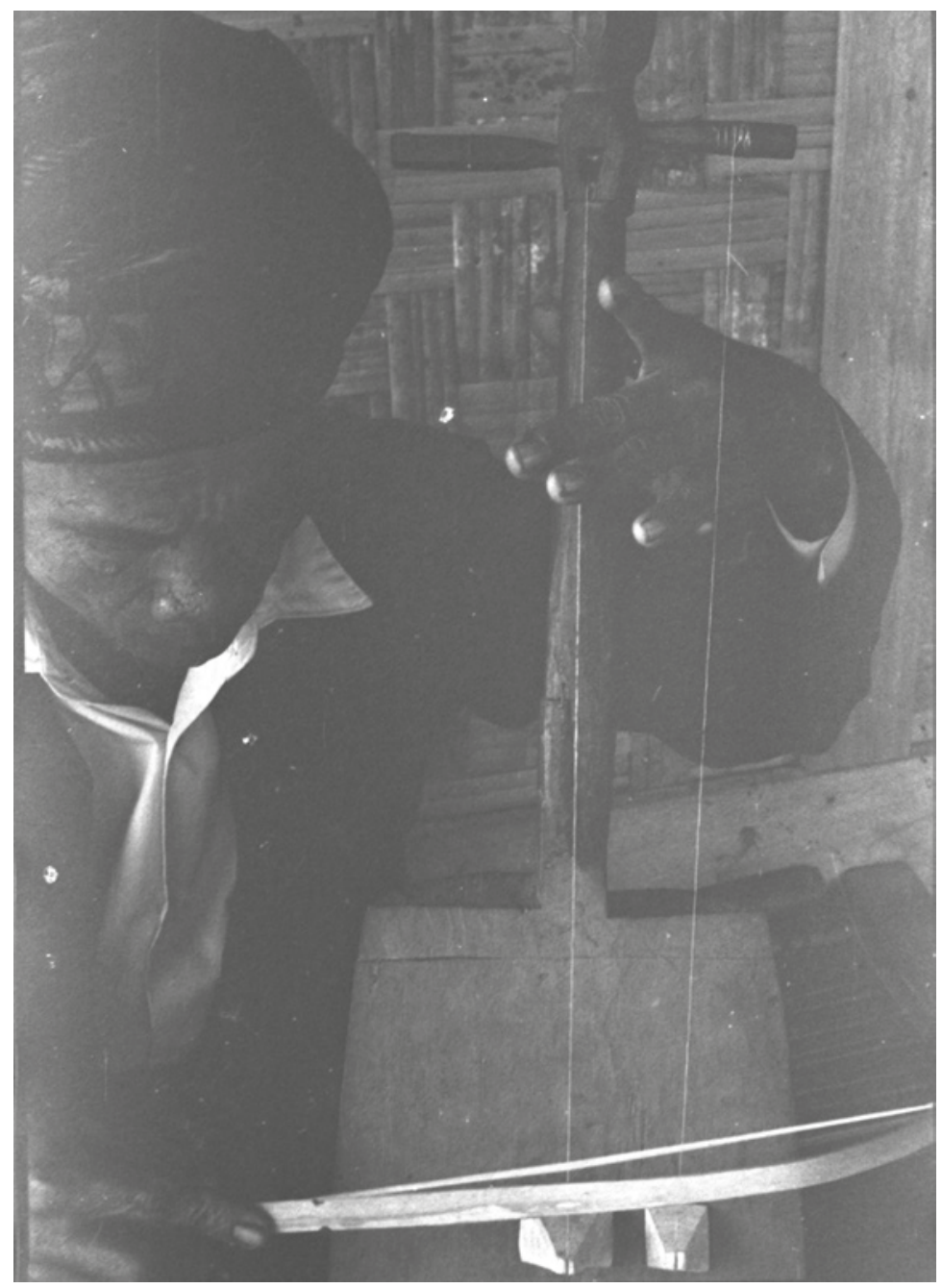

FIGURE 53 The position of the left hand in relation to the two strings of the rendo. Player Asmali from Nagrék (now called Cepakbungur or Cibungur?), recorded in Kompol, 26 July 1976

open string (Figure 53). The interval between the rendo strings is a fifth, and the higher right string is tuned after the 6th string of a kacapi, if the instruments are played together (A1992-2: 25-26). Compared to rebab playing, this technique is a kind of reversal: the rebab string on the player's left is bowed, and the right string is only occasionally used (Van Zanten 1989: 108, 129). The rendo is becoming a rare instrument and seems to become replaced by the violin (viol, biola), often locally made. 
Little is known about the history of the Baduy rendo. The word rendo is not known to most Sundanese and it does not appear in the Old Sundanese manuscripts discussed in Noorduyn and Teeuw (2006). However, at least one manuscript mentions the related two-string bowed lute tarawangs a found outside the Kanékés region (Noorduyn and Teeuw 2006: 417). In 1817 Raffles described the two-string bowed lute that is called tarawangsa nowadays as: 'trawángsa a musical instrument of the Sundas' (West Java). He also mentioned that the tarawangsa was 'by no means general'. The Baduy rendo is smaller than, but very similar to the Sundanese tarawangsa. However, the rendo does not have the wood carving on the top of the neck of the instrument, like shown on the pictures of tarawangsa by Raffles (1817: plate between pp.168-169, 472), and Pleyte (1907: after p.26). Did the Baduy develop their rendo from the tarawang$s a$ ? The village secretary Ukang Sukarna told me that the Baduy adopted the rendo from the people in Citorék (A1992-1: 41). I have no further evidence of this.

The rendo, tarawangsa and the kacapi all have their strings disappearing through holes in the soundboard. This construction makes these string instruments 'Sundanese' and the kacapi are in this respect definitely different from East Asian large zithers (see further Van Zanten 1989: 84-97). Unfortunately the pictures and additional information in printed books since 1817 (Raffles) do not give much solid information on the rendo. Both Van Hoëvell (1845: after p. 428) and Pleyte (1907: after p. 26) present pictures of what they call tarawangsa (and kacapi) and that show this special 'Sundanese' fixing of the strings. However, their tarawangsa pictures show instruments that have three strings, whereas the earlier picture of this instrument (Raffles 1817: plate between pp. 168-169) showed two strings, like the Baduy rendo that I recorded in 1976 and 1992; see also Figure 53 above.

Van Hoëvell $(1845: 428)$ seems to have been the first and only person to use the word 'rendo' in print before 1950 and he described it as 'a kind of trio, called rendo' consisting of zither, bowed lute and bamboo flute. The word rendo was used for an ensemble, not just for the bowed lute. He called the bowed Baduy lute tarawangsa and described it as 'a kind of violin, with three copper strings that are played with a bow made of horse hair attached to a bent bamboo stick'. Did Van Hoëvell really visit the (Outer) Baduy in Kanékés, or was he misled by the Baduy, as later authors suggested (Jacobs and Meijer 1891: 2; Pennings 1902: 378)? Did he visit the Karang group living near to Kanékés; was the instrument from there? See also Section 3.2 above. I was not able to solve the problem of where and when the Baduy rendo originated with the pictures and information from the past. On the available evidence is seems most likely that the Baduy started to develop their own two-string bowed lute (rendo) from examples they saw around them (tarawangsa), similarly to what happens now with the viol. 
Film $<\mathrm{AV}_{27}>$ shows a fragment of the trio consisting of kacapi (played by Yanci from Cisadané), rendo (played by Darmin, alias Daénah, from Cisaban) and lamus (possibly played by Ojél from Kadujangkung), recorded in Kadujangkung, 8 November 1992. The musicians play a 29-second excerpt of the song Adu Ua, also called Ngadu.

\subsubsection{Viol}

The Baduy viol is similar to the Indian and Western violin. When playing, the most common position is when one end is resting on the floor, like with the rendo (and rebab). Some players keep the instrument under the chin, like the Western violin. It seems that most Baduy viol (biola) players make their instrument and its bow themselves. Sardi (alias Anton, Omo) from Cikarého, Kompol, said that he made the body of the viol from lamé wood. Usually this was treated with varnish containing the bark of the gintung (gadog) tree that was also used to varnish the koja bags. For the bow (pangését) Sardi also used lamé wood and for the hair on the bow he used the plastic of fishing lines (kenur). The black hairy fibres around the sugar palm tree (injuk) and horse hair could also be used for the hair of the bow. The injuk gave a better sound, but it was more work to apply it. The viol strings were made from cable used for the brakes of a motor cycle. Sardi also possessed an old viol with a white tumbal cross on its soundboard, used to avert calamities (tolak bala). The resin (menyan) used for the hair of the bow was attached on two places on the side of the viol: see Figure 54 and A2014-1: 10-11.

The viol player Judi used the tuning of the strings, from right to left as seen from the player and from high to low as approximately: $\mathrm{g}^{2}, \mathrm{~d}^{2}, \mathrm{c}^{2}, \mathrm{~g}^{1}$ (recorded on DAT 92-08, 1:31:47-1:32:46, Gajéboh, 17 October 1992). According to the zither player Satra the strings of the Baduy violin are tuned according to the kacapi strings, in the saléndro tone system, and the total range covers one octave: the 1st, 2nd, 3rd and 4th string of the viol are tuned (from high to low, right to left) according to the 1 st, 3 rd, 4 th and 6 th kacapi string. Hence the intervals between the strings of the violin, from high to low are more or less: one Western fourth (about 500 cent), a major second (about 200 cent), and again one fourth. According to Satra the lowest viol string is rarely used when playing (A2003-2:14). Sardi from Kompol confirmed that he tuned the strings of his viol with intervals of a fourth, a second and again a fourth, and corresponding to the saléndro tuning of the kacapi strings 1, 3, 4, 6 .

\subsubsection{Rebab}

In current practice the rebab is forbidden to all Baduy. In the 1970s and earlier the rebab apparently was allowed to play with the keromong ensemble in the Outer Baduy area. The rebab is very important in the Sundanese saléndro 


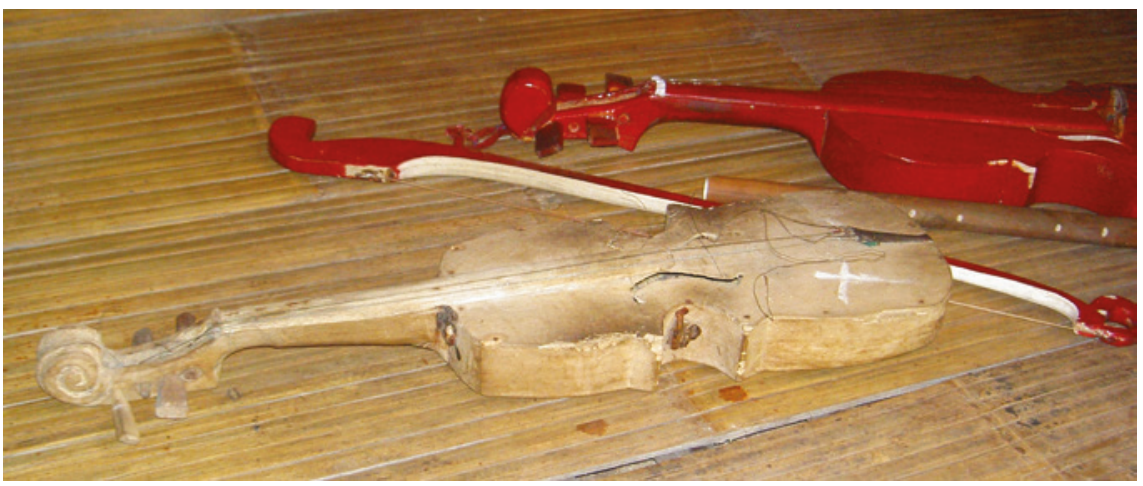

FIGURE 54 Old violin with white cross to avoid calamities; in the background a violin, bow and flute in construction by Sardi from Cikarého, Kompol, 26 May 2014

gamelan outside the Baduy community. As mentioned in Section 3.1, Bernard Suryabrata presumably made the earliest recordings of Baduy music in the RRI radio studio in Jakarta, starting in 1956 . Those early recordings include keromong music and the rebab is part of that ensemble, together with the suling lamus. The present author recorded the Baduy rebab playing in the keromong ensemble in June and July 1976 (Van Zanten 1995: 527). However, since about 1980 the rebab became forbidden in Kanékés. As already mentioned in Section 5.3 one of the reasons for this might be that the rebab is associated with Islam (Van Zanten (1989: 107-110).

\subsection{Xylophones and Jew's Harp}

\subsubsection{Gambang or Gambang Kayu}

The gambang or gambang kayu (wooden gambang) is a trough xylophone that is used in the Baduy keromong ensemble, but also on its own. The gambang as used in the keromong ensemble seem to have generally 14-16 wooden keys. However, the gambang in the keromong ensemble in Kompol, recorded in July 1976, had twenty keys (see film $<$ AVo6 $>$ ). The only gambang that I recorded on its own, in Jakarta on 9 September 1976, had ten wooden keys and the resonator trough was carved from a single block of wood (see Figure 55). The larger gambang have troughs made from planks fixed together with nails.

The keys lie loose on a thick piece of rope or rubber and a few nails between the keys may keep them more or less in place. They are arranged in such a way that the frequency in Hertz of the produced tones is increasing from left to right, as seen from the player. The tuning is supposed to be equidistant 


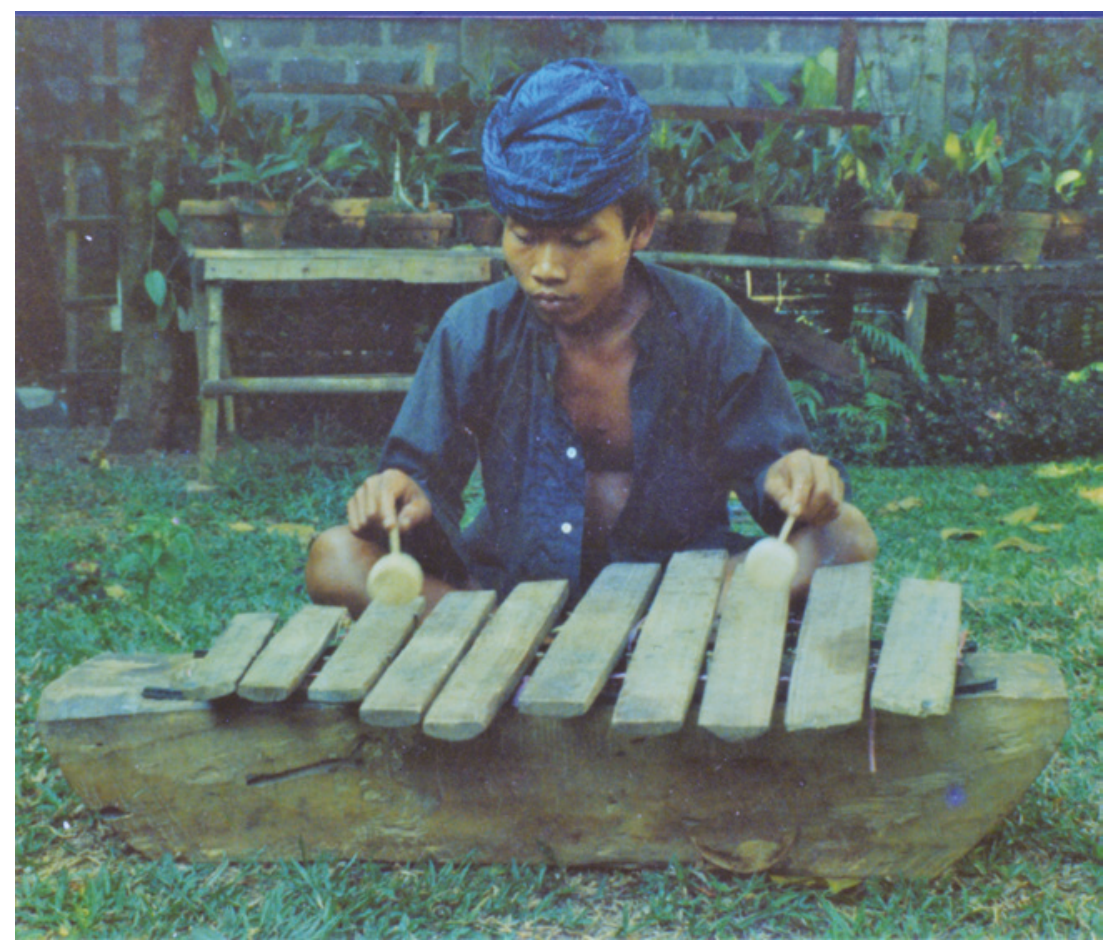

FIGURE 55 Gambang (kayu) with ten keys lying over a wooden trough in one piece, played by Injal from Gajéboh in Jakarta, 9 September 1976

pentatonic (saléndro) and with their two beaters the players seem to play mostly in octaves, that is, they simultaneously hit keys lying 5 keys apart: 1 and 6,2 and 7 , etc. This needs further investigation.

In Sections 4.4, 4.5, 5.3 and 5.4 above I have described that since about $2005^{-2010}$ the keromong ensemble started to include two gambang xylophones. One is used to play the melody and the other one, the gambang kendang (drum xylophone), takes the role of the drum, which is very pronounced in Sundanese gamelan, but not allowed with the Baduy keromong (see also Van Zanten 2015).

I have no detailed information on the wood used for making gambang parts: the trough, the keys and the beaters. It seems that currently Baduy tend to use stronger wood for the keys (teak or iron wood) than in the past. The small gambang that was played by Injal and that I recorded in September 1976 in Jakarta (Figure 55) does not consist of this very strong wood. The instrument was made by Sanusi from Kaduketug and I bought it for $\mathrm{Rp} 8000$ (then about $€ 18$, us $\$ 2$; see also Table 3 in Section 2.6). This gambang kayu, played solo by 
Injal in Jakarta, September 1976, may be heard in $<\mathrm{AV}_{2} 8>$ in the piece Reundeu Beureum.

\subsubsection{Calung}

The calung is also a xylophone, but the keys are made from bamboo and similar in shape to the bamboo tubes as used in the angklung instruments. There are a few different forms of the calung. I have only recorded (and bought) a calung, played as a single instrument in the form of a xylophone in September 1976 and not seen the instrument around afterwards. The frame of this instrument is a light construction of bamboo and the 16 keys are fixed with a chord to this frame: see Figure 56 (see also the lower picture of calung rantay in Soepandi 1995b: 46). The calung xylophone in Figure 56 was, like the gambang kayu in Figure 55, made by Sanusi from Kaduketug and it took him three days. I also bought this instrument for Rp 8000 (about $€ 18$, us $\$ 20$ at that time; see also Table 3).

The arrangement of the keys is similar to the gambang, with the low frequency notes on the left and the high frequency notes on the right as seen from the player. The playing is done with two beaters and the simultaneous notes seem to be mostly one octave apart, like in the playing of the gambang xylophone. The Ensiklopedi Sunda (2000) mentions that this type of calung or calung gambang is usually called gambang rancag in Kanékés.

Van Hoëvell (1845: opposite p. 357, 429-430) presents a drawing and describes a slightly different Baduy calung with twelve keys attached to two chords. The chords are not attached to a bamboo frame, but tied to a tree at one end and kept between the knees of the player sitting on the ground at the other end. It looks like a rope ladder and with the larger keys above. According to Van Hoëvell the player uses two sticks from a soft wood, like kapok (randu), to hit the keys. This kind of bamboo xylophone is called calung rénténg in the Ensiklopedi Sunda (2000). I have not seen this type of calung in or around Kanékés. However, the calung rantay or calung rénténg is presented with a video of the music recorded in 2017 on http://www.auralarchipelago.com/auralarchipelago/calung [last access 11 April 2019]. The calung keys are sometimes fixed on just one stick and thus become portable; this type is called calung jingjing (see pictures in Masunah et al 2003-1: 16, and Soepandi 1995b: 46-48). On the audio recording $<\mathrm{AV}_{29}>$ Sarjai plays the piece Aceuk on the calung xylophone in Figure 56 in Jakarta, 9 September 1976 (2'33").

\subsubsection{Karinding}

The karinding is a Jew's harp (or trump) made of a piece of about $8 \mathrm{~cm} \mathrm{x}$ $1.4 \mathrm{~cm}$ of the rib of a sugar palm (kawung) leaf or bamboo (A2003-2: 5; Van 


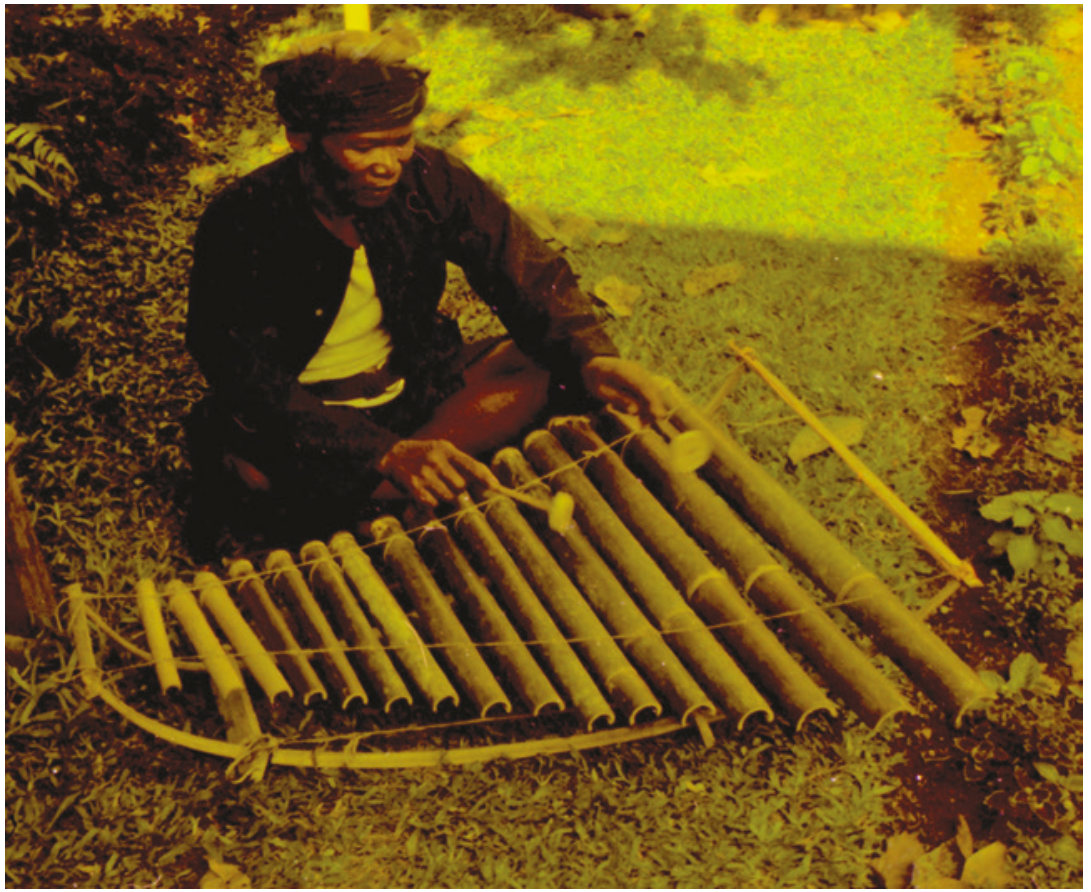

FIGURE 56 Calung xylophone with 16 keys played by Sarjai from Gajéboh in Jakarta, 9 September 1976

Zanten (1995: 525)). The sound of this idiophone is produced by a vibrating lamella, reed or tongue that is cut out of the body and only attached to it on one of the small sides. The Baduy karinding is placed on the small flat part cut out of a bamboo tube of about $40 \mathrm{~cm}$ long and open at both ends to produce a better resonance: see Figure 57. In this picture the lower karinding is shown upside-down, as seen from the player..$^{12}$ The player keeps the resonator and the karinding in his left hand, such that the loose end of the vibrating strip is just inside his open mouth. Beating with the right hand on the karinding frame, causes the narrow lamella to vibrate and produce a tone. By changing the shape of the mouth some overtones in the frequency spectrum become louder. This is a well-known principle for Jew's harps all over the world. Film $<\mathrm{AV}_{30} \mathrm{O}\left(47^{\prime \prime}\right)$ shows two men playing karinding together in

12 Kunst (1973: 360) mentions that in west Java one end of this resonator tube is sometimes resting on the ground 'when playing in a squatting position' while the other end is kept near the mouth and the karinding. This would implicate that the resonator tube would be $60-80 \mathrm{~cm}$ long; however, Kunst does not give a picture of such long resonator tube. 


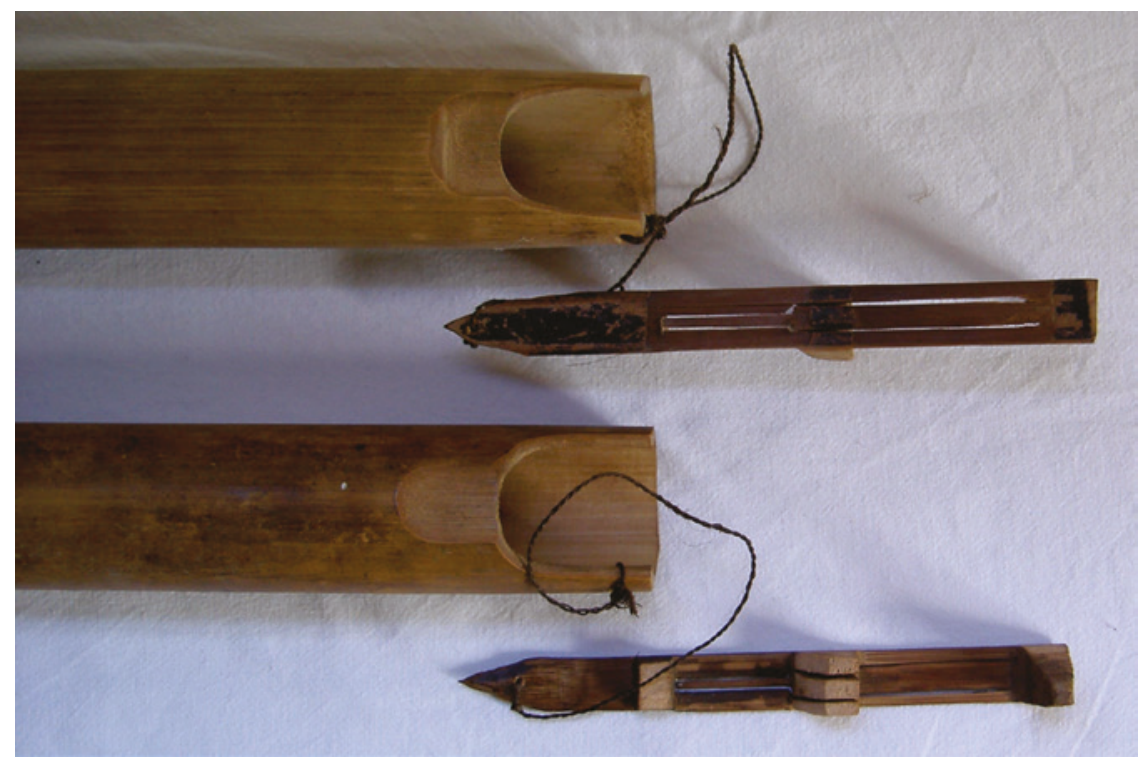

FIGURE 57 Two karinding Jew's harps with resonator made by Karamaén from Cibéo in 2003. The upper instrument is in the correct position and the lower one upside-down, as seen from the player

Gajéboh, July 1976. See also photographs in Kunst 1973: Vol.2: 443 and Van Zanten 1995: $5^{26 .}$

Soepandi (1995a: 18) mentions that the karinding is made from bunar, a thin kind of tamiang (Eringa 1984) or talang bamboo. ${ }^{13}$ Pleyte (1912: 258) gives a short Baduy poem (bangbalikan) in which it says that the karinding is made from the 'black sugar palm' (Na karinding kaung hideung).

The karinding is played by Inner and Outer Baduy, both men and women. Nowadays the karinding seems a rarely played instrument in the Outer Baduy area. The instrument may be played for entertainment, but the playing was (is?) often used for courting purposes. An unmarried girl or boy may use her/ his karinding playing to attract the attention of an unmarried boy/girl. The former secretary (carik) of Kanékés Ukang Sukarna said in 2003 that the karinding may also produce sounds that refer to words in a susualan stanza (A20032:13). In 2003 Karamaén from Cibéo described the importance of the karinding to the Inner Baduy by saying that this was also music 'to entertain Déwi Asri', the goddess of rice. He also said that the roots of rice plants were often eaten

13 Schizostachyum brachycladum Kurz (Sastrapradja et al. 1977: 48-49). 
by the mole cricket (gaang). However, this harmful insect was afraid of the sound of the karinding and therefore it could be chased away by playing this instrument (A2003-2: 5). According to the Ensiklopedia Sunda (2000) the karinding used to be played by boys herding buffalo's or sheep (outside Kanékés), like the earlier mentioned elét.

I recall that the karinding is also used in the go-goongan ensemble, established around 2012-2013 and discussed in Section 1.2. Listen to the audio fragment $<\mathrm{AV}_{32}>\left(1^{\prime} 50^{\prime \prime}\right)$ of the song Buah Gedang, made in Cipondok on 1 July 2014. The recording was made while moving around with the digital recording machine and built-in microphone to get the different instruments singled out; first the siter is relatively loud (with singing, etcetera) and after about 1 minute the karinding can clearly be heard. It remains to be seen how this go-goongan music will develop in the coming years.

See also Spiller (2015) about the revival of the Sundanese karinding. In his article Spiller (2015:155) also mentioned that Sundanese karinding was recorded at the 1893 World's Columbian Exposition in Chicago by Benjamin Ives Gilman. According to Daryana (2017: 357, 359, 361), in the area around Bandung the Jew's harp has successfully been integrated into new forms of music, resulting in about 200 'karinding music groups' in 2016. This apparently was achieved since 2008, mainly through the music band Karinding Attack (= Karat), founded by the pioneers of the Metal music community Ujungberung Rebels. These music groups have also shown interest in the 'traditional' (buhun) forms of karinding playing. Elsewhere in the world the integration of Jew's harps in pop music has been going on already for several decades.

In earlier chapters I have described music that may be used for ritual purposes, like angklung and pantun. In the present chapter I focussed on music of Baduy instruments that may be played on their own, or in combination with a few other instruments. This music is mainly for entertainment, like the susualan discussed in Chapter 7 . This type of music is less bound to the seasons for planting and harvesting rice, marriages and circumcisions. These instruments can always be played, except for the special fasting days in each of the three kawalu fasting months (see Table 5, Section 4.1).

I devoted relatively much attention to the side-blown flutes, kumbang and tarawélét, because these instruments seem to have become rare in the Outer Baduy region. On the whole we still lack detailed information on instruments in the Sundanese rural areas. This chapter was a modest attempt to correct this in the very limited area of the Baduy.

As mentioned in Section 1.3, one of the purposes of this book is to supply a context for better understanding the audio-visual recordings (films, photographs and audio) that I made of the Baduy in and around Kanékés between 
1976 and 2016. Other questions I addressed in this book are the role of music and dance in Baduy society and how the Indonesian authorities have been dealing with the intangible cultural heritage of this indigenous group. The following and last chapter will briefly come back to some of the central issues of this book: the sustainability of the Baduy community and their music and dance in the Indonesian context. It further suggest a few topics that could be researched in future. 